Atmos. Chem. Phys., 17, 10691-10707, 2017

https://doi.org/10.5194/acp-17-10691-2017

(c) Author(s) 2017. This work is distributed under

the Creative Commons Attribution 3.0 License.

\title{
Changes in ozone and precursors during two aged wildfire smoke events in the Colorado Front Range in summer 2015
}

\author{
Jakob Lindaas ${ }^{1}$, Delphine K. Farmer ${ }^{2}$, Ilana B. Pollack ${ }^{1,2}$, Andrew Abeleira ${ }^{2}$, Frank Flocke ${ }^{3}$, Rob Roscioli ${ }^{4}$, \\ Scott Herndon ${ }^{4}$, and Emily V. Fischer ${ }^{1}$ \\ ${ }^{1}$ Colorado State University, Department of Atmospheric Science, Fort Collins, CO, USA \\ ${ }^{2}$ Colorado State University, Department of Chemistry, Fort Collins, CO, USA \\ ${ }^{3}$ National Center for Atmospheric Research, Boulder, CO, USA \\ ${ }^{4}$ Aerodyne Research Inc., Billerica, MA, USA \\ Correspondence to: Jakob Lindaas (jlindaas@rams.colostate.edu) and Emily V. Fischer (evf@rams.colostate.edu)
}

Received: 26 February 2017 - Discussion started: 1 March 2017

Revised: 30 June 2017 - Accepted: 4 August 2017 - Published: 12 September 2017

\begin{abstract}
The relative importance of wildfire smoke for air quality over the western US is expected to increase as the climate warms and anthropogenic emissions decline. We report on in situ measurements of ozone $\left(\mathrm{O}_{3}\right)$, a suite of volatile organic compounds (VOCs), and reactive oxidized nitrogen species collected during summer 2015 at the Boulder Atmospheric Observatory (BAO) in Erie, CO. Aged wildfire smoke impacted BAO during two distinct time periods during summer 2015: 6-10 July and 16-30 August. The smoke was transported from the Pacific Northwest and Canada across much of the continental US. Carbon monoxide and particulate matter increased during the smoke-impacted periods, along with peroxyacyl nitrates and several VOCs that have atmospheric lifetimes longer than the transport timescale of the smoke. During the August smokeimpacted period, nitrogen dioxide was also elevated during the morning and evening compared to the smoke-free periods. There were nine empirically defined high- $\mathrm{O}_{3}$ days during our study period at $\mathrm{BAO}$, and two of these days were smoke impacted. We examined the relationship between $\mathrm{O}_{3}$ and temperature at $\mathrm{BAO}$ and found that for a given temperature, $\mathrm{O}_{3}$ mixing ratios were greater $(\sim 10 \mathrm{ppbv})$ during the smoke-impacted periods. Enhancements in $\mathrm{O}_{3}$ during the August smoke-impacted period were also observed at two long-term monitoring sites in Colorado: Rocky Mountain National Park and the Arapahoe National Wildlife Refuge near Walden, CO. Our data provide a new case study of how aged wildfire smoke can influence atmospheric composition
\end{abstract}

at an urban site, and how smoke can contribute to increased $\mathrm{O}_{3}$ abundances across an urban-rural gradient.

\section{Introduction}

Over the past 30 years, wildfires in the western US have increased in both frequency and intensity, and this trend will likely continue under future climate change (Westerling, 2016). Wildfire smoke can be transported over thousands of kilometers, and exposure to wildfire smoke has significant impacts on human health (Künzli et al., 2006; Rappold et al., 2011; Elliott et al., 2013). While US emissions of most major air pollutants are declining (Pinder et al., 2008), increasing fire activity suggests that wildfires may have a greater relative impact on US air quality in the future (Val Martin et al., 2015).

Ozone $\left(\mathrm{O}_{3}\right)$ is formed when hydrocarbons are oxidized in the presence of nitrogen oxides $\left(\mathrm{NO}_{x}=\mathrm{NO}+\mathrm{NO}_{2}\right)$ and sunlight (Sillman, 1999). Wildfires emit many trace gas species that contribute to tropospheric $\mathrm{O}_{3}$ production. Along with carbon monoxide $(\mathrm{CO})$, methane $\left(\mathrm{CH}_{4}\right)$, and carbon dioxide $\left(\mathrm{CO}_{2}\right)$, hundreds of different non-methane volatile organic compounds (NMVOCs) with lifetimes ranging from minutes to months (Atkinson and Arey, 2003) are emitted during biomass burning (Akagi et al., 2011; Gilman et al., 2015). Due to relatively large emissions of $\mathrm{CO}_{2}, \mathrm{CO}, \mathrm{CH}_{4}$, and $\mathrm{NO}_{x}$, the contribution of VOCs to the total emissions from fires on a molar basis is small $(<1 \%)$. However, VOCs 
dominate the $\mathrm{OH}$ reactivity in smoke plumes (Gilman et al., 2015). Recent observations of the evolution of VOCs within aging smoke plumes indicate that $\mathrm{OH}$ can be elevated in young biomass burning plumes (Hobbs et al., 2003; Yokelson et al., 2009; Akagi et al., 2012; Liu et al., 2016) in part due to the photolysis of oxygenated VOCs (Mason et al., 2001), which make a large contribution to the total emitted VOC mass (Stockwell et al., 2015). Elevated OH may reduce the lifetime of emitted VOCs and increase oxidation rates and potential $\mathrm{O}_{3}$ production.

Fires are also a major source of oxidized nitrogen; emissions from biomass and biofuel burning represent approximately $15 \%$ of total global $\mathrm{NO}_{x}$ emissions (Jaegle et al., 2005). However, there are major uncertainties in $\mathrm{NO}_{x}$ emission estimates from biomass burning, particularly at a regional scale (Schreier et al., 2015). $\mathrm{NO}_{x}$ emissions depend on the nitrogen content of the fuel (Lacaux et al., 1996; Giordano et al., 2016) as well as the combustion efficiency (Goode et al., 2000; McMeeking et al., 2009; Yokelson et al., 2009). Emitted $\mathrm{NO}_{x}$ is quickly lost in the plume, either by conversion to $\mathrm{HNO}_{3}$ (Mason et al., 2001) or via PAN formation (Alvarado et al., 2010; Yates et al., 2016). $\mathrm{HNO}_{3}$ is not often observed in plumes because it either rapidly forms ammonium nitrate or is efficiently scavenged by other aerosols (Tabazadeh et al., 1998; Trentmann et al., 2005).

There are multiple lines of observational evidence indicating that wildfires in the western US increase the abundance of ground-level $\mathrm{O}_{3}$. Background $\mathrm{O}_{3}$ mixing ratios across the western US are positively correlated with wildfire burned area (Jaffe et al., 2008), and daily episodic enhancements in $\mathrm{O}_{3}$ at ground sites can be $>10 \mathrm{ppbv}$ ( $\mathrm{Lu}$ et al., 2016). There are well-documented case studies of within-plume $\mathrm{O}_{3}$ production (see Jaffe and Wigder, 2012; Heilman et al., 2014, and references within) and time periods where smoke contributed to exceedances of the US EPA National Ambient Air Quality Standard (NAAQS) for $\mathrm{O}_{3}$ (Morris et al., 2006; Pfister et al., 2008), currently a maximum daily $8 \mathrm{~h}$ average of 70 ppbv. Brey and Fischer (2016) investigated the impacts of smoke on $\mathrm{O}_{3}$ abundances across the US via an analysis of routine in situ measurements and NOAA satellite products. Their analysis demonstrated that the presence of smoke is correlated with higher $\mathrm{O}_{3}$ mixing ratios in many areas of the US, and that this correlation is not driven by temperature. Regions with the largest smoke-induced $\mathrm{O}_{3}$ enhancements (e.g., the southeast and Gulf Coast) can be located substantially downwind of the wildfires producing the most smoke.

Despite several recent studies showing that smoke contributes to elevated $\mathrm{O}_{3}$, there have been relatively few detailed studies of wildfire smoke mixing with anthropogenic air masses near the surface. Morris et al. (2006) demonstrated that smoke from wildfires in Alaska and Canada exacerbated ozone pollution in Houston during 2 days in July 2004, but did not have in situ measurements of other chemical species apart from $\mathrm{O}_{3}$. Singh et al. (2012) used aircraft measurements from summer 2008 over California to document sig- nificant $\mathrm{O}_{3}$ enhancements in nitrogen-rich urban air masses mixed with smoke plumes. Accompanying air quality simulations were not successful in capturing the mechanisms responsible for these enhancements. In general, measurements of $\mathrm{O}_{3}$ precursors are hard to make routinely. Instrumentation and calibration methods tend to be time and labor intensive, and thus unpredictable wildfire smoke plumes and their effects on surface $\mathrm{O}_{3}$ are sparsely sampled.

Here we present a case study of aged wildfire smoke mixed with anthropogenic pollution in the Colorado Front Range and show its impact on atmospheric composition and $\mathrm{O}_{3}$. The Northern Colorado Front Range region violates the NAAQS for $\mathrm{O}_{3}$, and has been the focus of several recent studies (e.g., McDuffie et al., 2016; Abeleira et al., 2017). First we describe the research location and measurements. Next, we identify the smoke-impacted time periods and show the origin, approximate age, and wide horizontal extent of the smoke plumes. We characterize significant changes in atmospheric composition with respect to the two major classes of $\mathrm{O}_{3}$ precursors, VOCs and oxidized reactive nitrogen $\left(\mathrm{NO}_{y}\right)$. Finally, we present the impact of smoke on $\mathrm{O}_{3}$ abundances during this period and discuss the underlying causes of this impact.

\section{Measurements and research site}

During summer 2015, we made measurements of a suite of trace gases at the Boulder Atmospheric Observatory (BAO), located north of Denver, $\mathrm{CO}$, in the middle of the rapidly developing northern Colorado Front Range $\left(40.05^{\circ} \mathrm{N}, 105.01^{\circ} \mathrm{W} ; 1584 \mathrm{~m}\right.$ a.s.l.). BAO has a history of atmospheric trace gas and meteorological measurements stretching back nearly 4 decades (Kelly et al., 1979; Gilman et al., 2013). Our research campaign from 1 July-7 September 2015 measured a suite of $\mathrm{O}_{3}$ precursor species as well as several $\mathrm{NO}_{x}$ oxidation products and greenhouse gases. The intended goal of the field campaign was to improve our understanding of the complex $\mathrm{O}_{3}$ photochemistry in the Colorado Front Range and the contributions of oil and natural gas activities as well as other anthropogenic emissions to $\mathrm{O}_{3}$ production. All measurements were made by instruments housed in two trailers located at the base of the BAO tower. Here we briefly describe the measurements used in this paper. Data are available at https://esrl.noaa.gov/csd/groups/csd7/ measurements/2015songnex/.

We measured $\mathrm{CO}$ and $\mathrm{CH}_{4}$ at $\sim 3 \mathrm{~s}$ time resolution with a commercial cavity ring-down spectrometer (Picarro, model G2401; Crosson, 2008). The inlet was located $6 \mathrm{~m}$ above ground level (a.g.l.), and a PTFE filter membrane with $1 \mu \mathrm{m}$ pore size (Savillex) at the inlet was changed weekly. Laboratory instrument calibrations were performed pre- and post-campaign using three NOAA standard reference gases (http://www.esrl.noaa.gov/gmd/ccl/refgas.html; CA06969, CB10166, and CA08244). Field calibration was 
performed every $3 \mathrm{~h}$ using high, low and middle reference gas mixtures (Scott Marin Cylinder IDs CB10808, CB10897, CB10881). Mixing ratios were calculated using the WMOCH4-X2004 and WMO-CO-X2014 scales. The uncertainty associated with the $\mathrm{CH}_{4}$ and $\mathrm{CO}$ data is estimated to be 6 and $12 \%$ respectively, and it was estimated as the quadrature sum of measurement precision, calibration uncertainty and uncertainty in the water vapor correction.

A custom four-channel cryogen-free gas chromatography (GC) system (Sive et al., 2005) was used to measure selected non-methane hydrocarbons ( $\mathrm{NMHCs}$ ), $\mathrm{C}_{1}-\mathrm{C}_{2}$ halocarbons, alkyl nitrates (ANs), and oxygenated volatile organic compounds (OVOCs) at sub-hourly time resolution; approximately one sample every $45 \mathrm{~min}$. The inlet was located at $6 \mathrm{~m}$ a.g.l. with a $1 \mu \mathrm{m}$ pore size Teflon filter. Ambient air for each sample was collected and pre-concentrated over $5 \mathrm{~min}$, with a $1 \mathrm{~L}$ total sample volume. A calibrated whole air mixture was sampled in the field after every 10 ambient samples to monitor sensitivity changes and measurement precision. A full description of this instrument and the associated uncertainties for each detected species is provided in (Abeleira et al., 2017).

Ozone data at BAO for this time period were provided by the NOAA Global Monitoring Division surface ozone network (McClure-Begley et al., 2014; data available at ftp. cmdl.noaa.gov/data/ozwv/SurfaceOzone/BAO/). Ozone was measured via UV absorption using a commercial analyzer (Thermo Scientific Inc., model 49), which is calibrated to the NIST standard over the range $0-200 \mathrm{ppbv}$ and routinely challenged at the site. The inlet height was $6 \mathrm{~m}$ a.g.l. on the BAO tower, located about $50 \mathrm{ft}(\sim 15 \mathrm{~m})$ from the two trailers, and measurements were reported at a 1 min averaging interval with an estimated error of $1 \%$.

Nitrogen oxides $\left(\mathrm{NO}_{x} \equiv \mathrm{NO}+\mathrm{NO}_{2}\right)$ and total reactive nitrogen $\left(\mathrm{NO}_{y}\right)$ were measured via $\mathrm{NO}-\mathrm{O}_{3}$ chemiluminescence detection (Kley and McFarland, 1980) using a commercial analyzer (Teledyne, model 200EU). Two commercial converters, a $395 \mathrm{~nm}$ LED converter (Air Quality Designs, Inc., model BLC) for chemically selective photolysis of $\mathrm{NO}_{2}$ to $\mathrm{NO}$ and a molybdenum in stainless steel converter (Thermo Scientific Inc.) heated to $320^{\circ} \mathrm{C}$ for reduction of $\mathrm{NO}_{y}$ to NO, were positioned as close to the inlet tip as possible $(<10 \mathrm{~cm})$. A $7 \mu \mathrm{m}$ stainless steel particulate filter was affixed to the upstream end of the molybdenum converter; otherwise no other filters were used. The analyzer switched between sampling from the LED $\left(\mathrm{NO}_{x}\right)$ converter and the molybdenum $\left(\mathrm{NO}_{y}\right)$ converter every $10 \mathrm{~s}$, and the LEDs were turned on (to measure $\mathrm{NO}+\mathrm{NO}_{2}$ ) and off (to measure $\mathrm{NO}$ only) every minute. $\mathrm{NO}_{2}$ was determined by subtraction of measured $\mathrm{NO}$ from measured $\mathrm{NO}+\mathrm{NO}_{2}$ divided by the efficiency of the LED converter. All three species are reported on a consistent 2 min average timescale. The detector was calibrated daily by standard addition of a known concentration of NO, NIST-traceable (Scott-Marrin Cylinder ID CB098J6), to synthetic ultrapure air. Both converters were calibrated with a known concentration of $\mathrm{NO}_{2}$ generated via gas phase titration of the $\mathrm{NO}$ standard. The $\mathrm{NO}_{y}$ channel was further challenged with a known mixing ratio of nitric acid $\left(\mathrm{HNO}_{3}\right)$ generated using a permeation tube (Kintech, $30.5 \pm 0.8 \mathrm{ng} \mathrm{min}^{-1}$ at $40^{\circ} \mathrm{C}$ ), which was used to confirm $>90 \%$ conversion efficiency of $\mathrm{HNO}_{3}$ by the molybdenum converter. Uncertainties of $\pm 5 \%$ for $\mathrm{NO}, \pm 7 \%$ for $\mathrm{NO}_{2}$, and $\pm 20 \%$ for $\mathrm{NO}_{y}$ are determined from a quadrature sum of the individual uncertainties associated with the detector, converters, and calibration mixtures; a limit of detection of $0.4 \mathrm{ppbv}$ for all species is dictated by the specifications of the commercial detector.

Peroxyacyl nitrates (PANs) were measured using the $\mathrm{Na}$ tional Center for Atmospheric Research gas chromatograph with an electron capture detector (NCAR GC-ECD; Flocke et al., 2005). The instrument configuration was the same as was used during the summer 2014 FRAPPE field campaign (Zaragoza, 2016). The NCAR GC-ECD analyzed a sample every $5 \mathrm{~min}$ from a $6 \mathrm{~m}$ a.g.l. inlet with $1 \mu \mathrm{m}$ pore size Teflon filter. A continuous-flow acetone photolysis cell generated a known quantity of PAN used to calibrate the system at $4 \mathrm{~h}$ intervals.

An Aerodyne dual quantum cascade laser spectrometer was used to measure $\mathrm{HNO}_{3}$ (McManus et al., 2011). The instrument employed a prototype $400 \mathrm{~m}$ absorption cell for increased sensitivity during the first month of the campaign, after which it was replaced by a $157 \mathrm{~m}$ absorption cell. An active passivation inlet (Roscioli et al., 2016) was used to improve the time response of the measurement to $\sim 0.75 \mathrm{~s}$. This technique utilized a continuous injection of $10-100 \mathrm{ppb}$ of a passivating agent vapor, nonafluorobutane sulfonic acid, into the inlet tip. The inlet tip was made of extruded perfluoroalkoxy Teflon (PFA), followed by a heated, fused silica inertial separator to remove particles larger than $300 \mathrm{~nm}$ from the sample stream. The inlet was located $8 \mathrm{~m}$ a.g.l. with a $18 \mathrm{~m}$ heated sampling line (PFA, $1 / 2$ in. diameter OD) to the instrument. The system was calibrated every hour by using a permeation tube that was quantified immediately prior to the measurement period.

\section{Smoke events}

We observed two distinct smoke-impacted periods at BAO, identified by large enhancements in $\mathrm{CO}$ and fine aerosol $\left(\mathrm{PM}_{2.5}\right)$. Figure 1 presents $\mathrm{CO}$ observations from $\mathrm{BAO}$ and fine particulate matter $\left(\mathrm{PM}_{2.5}\right)$ observations from the Colorado Department of Public Health and Environment (CDPHE) CAMP air quality monitoring site (www.epa.gov/ airdata), located in downtown Denver, approximately $35 \mathrm{~km}$ south of $\mathrm{BAO} . \mathrm{PM}_{2.5}$ was similarly elevated during the smoke-impacted periods at nine other CDPHE monitoring sites across the Colorado Front Range: BOU, CASA, CHAT, COMM, FTCF, GREH, I25, LNGM, NJH (Fig. S1 in the Supplement). For our analysis, we defined a July 


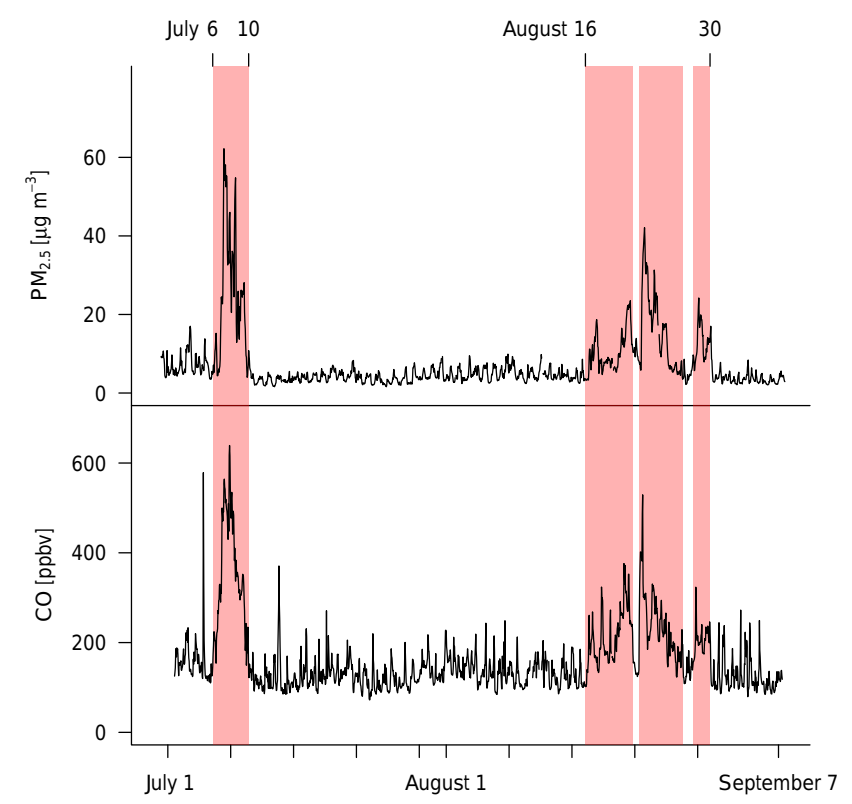

Figure 1. Top panel: time series of hourly $\mathrm{PM}_{2.5}$ concentrations for the CDPHE CAMP air quality monitoring site (www.epa.gov/ airdata) located in downtown Denver $\left(39.75^{\prime},-104.98^{\prime}\right)$. Bottom panel: time series of hourly $\mathrm{CO}$ mixing ratios at the Boulder Atmospheric Observatory (BAO: $\left.40.05^{\prime},-105.01^{\prime}\right)$. Red shading denotes periods during which smoke is present at BAO.

smoke-impacted period and an August smoke-impacted period. The July smoke-impacted period lasted for 4 days from 00:00 MDT 6 July 2015 to 00:00 MDT 10 July 2015. The August smoke-impacted period was significantly longer ( $\sim 14$ days). For the subsequent analysis, we combined three distinct waves of smoke impact in this 14-day period into one August smoke-impacted period: 00:00 MDT 16 August 2015 to 18:00 MDT 21 August 2015, 12:00 MDT 22 August 2015 to 18:00 MDT 27 August 2015, and 14:00 MDT 28 August 2015 to 09:00 MDT 30 August 2015. We omitted the brief periods between these times from the analysis due to uncertainty on the influence of smoke during them. All other valid measurements were considered part of the smoke-free data.

Figure 2 presents the extent of the presence of smoke in the atmospheric column during representative smoke-impacted days, 7 July and 21 August 2015. The NOAA Hazard Mapping System smoke polygons show that the smoke events observed at BAO were large regional events. The HMS smoke product is produced using multiple NASA and NOAA satellite products (Rolph et al., 2009). Smoke in the atmospheric column is detected using both visible and infrared imagery and is fully described in Brey et al. (2017). The extent of smoke plumes within the HMS dataset represents a conservative estimate, and no information is provided on the vertical extent or vertical placement of the plumes. Figure 2 also shows active MODIS fire locations for the previous day (Giglio et al., 2003, 2006) and 5-day NOAA Air Re- sources Laboratory Hybrid Single Particle Lagrangian Integrated Trajectory (HYSPLIT) back trajectories initialized each hour of the day from BAO at $1000 \mathrm{~m}$ above ground level (Stein et al., 2015). Trajectories were run using the EDAS (Eta Data Assimilation System) $40 \mathrm{~km} \times 40 \mathrm{~km}$ horizontal resolution reanalysis product (Kalnay et al., 1996). In total, Fig. 2 demonstrates that the smoke that impacted BAO during both periods was transported from large extreme fire complexes in the Pacific Northwest and Canada, with approximate transport timescales of the order of 2-3 days. Front Range surface temperatures were not anomalously high in July and August 2015 based on a comparison of reanalysis data for this period to the 1981-2010 climatology. Surface precipitation, surface relative humidity, and soil moisture in the Front Range were all lower than this referent period. The extreme fires in Washington and Idaho were associated with warmer and drier than average summer temperatures in the Pacific Northwest (Kalnay et al., 1996). Creamean et al. (2016) provide a more detailed description of smoke transport and the sources of the aerosols associated with the August smoke-impacted period. Summer 2015 was the largest wildfire season in Washington, and the Okanogan Complex fire, which likely contributed to the smoke observed at BAO, was the largest fire complex in state history. Summer 2015 was also one of the largest fire seasons for northern Idaho, with approximately 740000 acres burned.

\section{Observed changes in ozone and its precursors}

\section{1 $\mathrm{CO}, \mathrm{CH}_{4}$, and VOC abundances}

We quantified $\mathrm{CO}, \mathrm{CH}_{4}$, and $40+$ VOC species including $\mathrm{C}_{2}-\mathrm{C}_{10}$ non-methane hydrocarbons (NMHCs), $\mathrm{C}_{1}-\mathrm{C}_{2}$ halocarbons, and several oxygenated species (methyl ethyl ketone, acetone, and acetaldehyde) at BAO. The focus of the BAO field intensive was to study the photochemistry of local emissions from oil and gas development (e.g., Gilman et al., 2013; Swarthout et al., 2013; Thompson et al., 2014; Abeleira et al., 2017), and the GC system was not set up to quantify species with known large biomass burning emission ratios (e.g., hydrogen cyanide, acetonitrile, most oxygenated organic species; Akagi et al., 2011). The system did not have a mass spectrometer online, and the calibration standards did not contain $\mathrm{HCN}$ and acetonitrile. Thus the detection of these species was not possible. In addition, early campaign issues with the online multichannel gas chromatography system compromised the data for the July smoke period and thus we restrict our comparison of VOCs in smoke-free versus smoke-impacted periods to a comparison between 16-30 August, the August smoke-impacted period, and 24 July-16 August, the smoke-free period. The brief smoke-free times during 16-30 August (denoted by white between the red shading in Fig. 1) were not included in either period since it is difficult to determine whether they were smoke-impacted. GC 
(a)

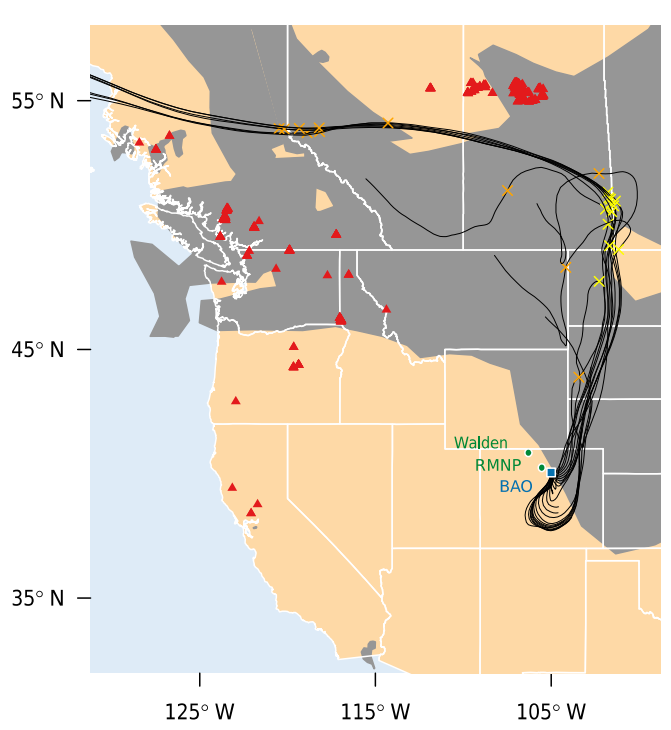

(b)

August 21, 2015

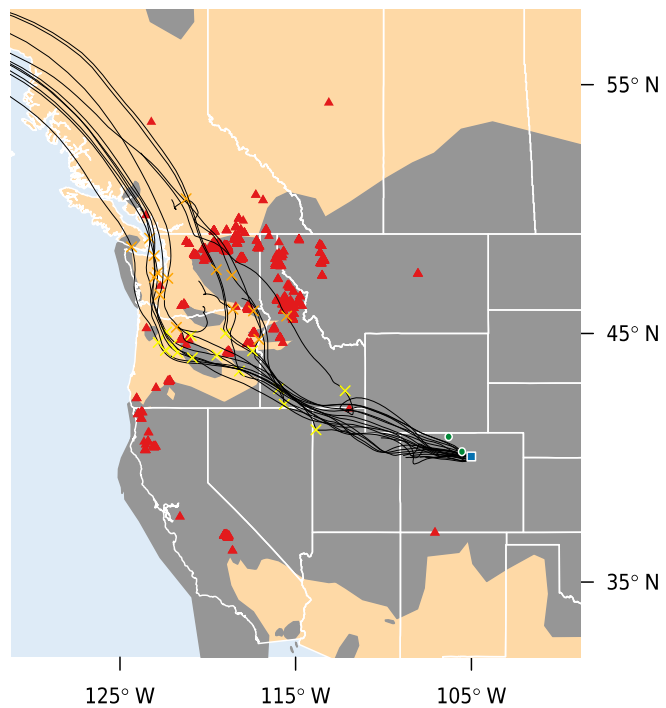

Figure 2. Representative days during each smoke period observed at the Boulder Atmospheric Observatory (BAO: blue square). NOAA Hazard Mapping System (http://www.ssd.noaa.gov/PS/FIRE/) smoke polygons are plotted in dark gray shading with MODIS fire locations (http://modis-fire.umd.edu/index.php) from the previous day plotted as red triangles. The thin black lines show HYSPLIT $120 \mathrm{~h}$ back trajectories from the BAO site initiated at $1000 \mathrm{~m}$ a.g.l. for each hour of the day plotted. Yellow cross-hatches display the location of each trajectory $48 \mathrm{~h}$ back and orange cross-hatches indicate the $72 \mathrm{~h}$ location. The green points show the location of the Rocky Mountain National Park and Walden measurement locations.

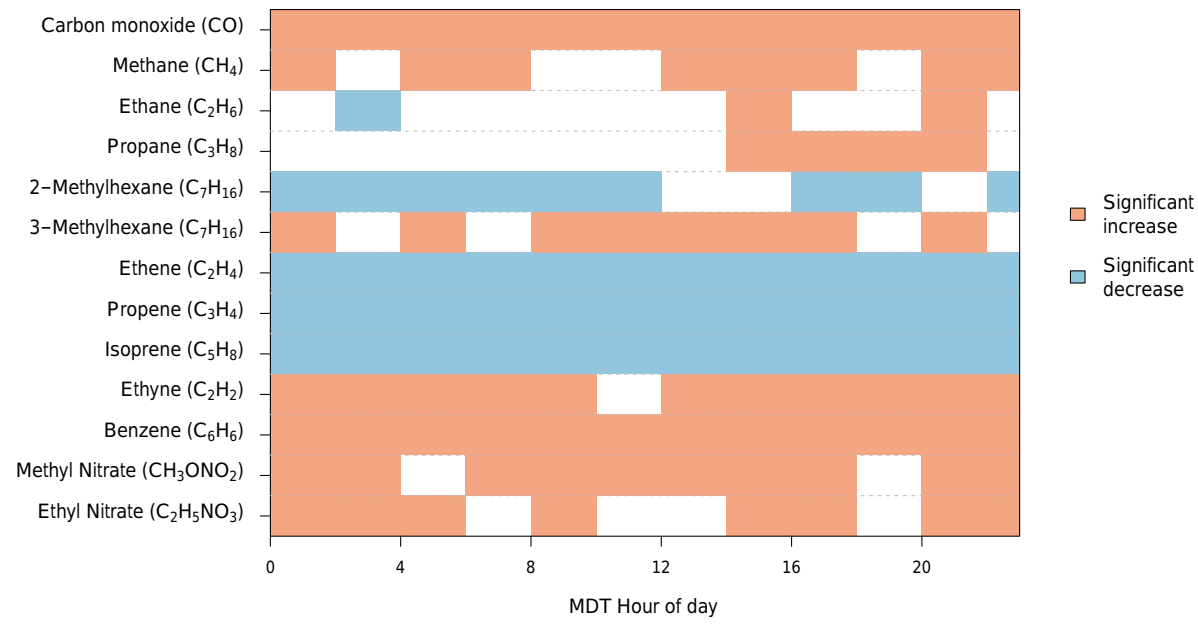

Figure 3. Significant changes (two-sided Student's $t$ test, $90 \%$ confidence interval) in hourly averaged mixing ratios of a subset of species measured at BAO between smoke-free periods and the 16-30 August smoke period. Significant increases during smoke-impacted periods compared to smoke-free periods are shown in red; significant decreases are in blue.

measurements were made approximately every $45 \mathrm{~min}$ and we compared 251 measurements of VOCs during the August smoke period to 583 measurements during the smoke-free period. A statistical summary of all VOC measurements for each period is available in Table S1 in the Supplement.

In this section, we describe significant changes in VOC abundances and notable exceptions. The HYSPLIT trajectories (Fig. 2) suggest that the age of the smoke impacting the
Front Range during the August smoke period was 2-3 days. We observed enhancements in the abundances of $\mathrm{CO}, \mathrm{CH}_{4}$, and VOCs with lifetimes longer than the transport time of the smoke, with the exception of some alkanes that have a large background concentration in the Front Range due to emissions from oil and gas production. Three of the alkenes we quantified (isoprene, ethene, and propene) were generally near the limit of detection during the August smoke-impacted 
period, although notably cis-2-butene abundances were not changed. Significant differences were not observed in the four oxygenated VOCs quantified between smoke-impacted and smoke-free periods.

Mean hourly $\mathrm{CO}$ mixing ratios were significantly enhanced by $223 \mathrm{ppbv}$, or $170 \%$ during the July smokeimpacted period and by $92 \mathrm{ppbv}$, or $70 \%$, during the August smoke-impacted period (Fig. 1). This enhancement was present across the diurnal cycle (Fig. 3) and both smoke periods displayed a higher range of $\mathrm{CO}$ mixing ratios (July: 127-639 ppbv; August: 101-529 ppbv; smokefree: $72-578 \mathrm{ppbv})$. The two smoke periods differed in their sources fires, length, and meteorology, with higher average $\mathrm{CO}$ and $\mathrm{PM}_{2.5}$ measurements in the July smoke period (Fig. 1). Average enhancements of $\mathrm{CH}_{4}$ were similar for both periods (July: $52 \mathrm{ppbv}$; August: $50 \mathrm{ppbv}$; or $\sim 2.5 \%$ increase). Methane has a relatively high background at BAO due to large emissions of $\mathrm{CH}_{4}$ in nearby Weld County from livestock production and oil and gas development (Pétron et al., 2014; Townsend-Small et al., 2016). Taken together, the larger background of $\mathrm{CH}_{4}$ and the large local sources of $\mathrm{CH}_{4}$ in the Front Range served to mute the impact of the August smoke on overall $\mathrm{CH}_{4}$ abundances. The diurnal cycle of $\mathrm{CH}_{4}$ did not change during the smoke-impacted period as compared to the smoke-free period and we observed a similar range of mixing ratios $(\sim 1840-3360 \mathrm{ppbv})$ in the both smoke-free and smoke-impacted periods. We note several large spikes in $\mathrm{CH}_{4}$ of the order of minutes during the August smoke-impacted period, but we do not believe that these are related to the presence of smoke because they were not correlated with similar excursions in CO and PANs, and exhibited strong correlations with propane and other tracers of oil and gas and other anthropogenic activity. Due to the availability of valid data, the rest of the discussion on VOC composition will focus on changes during the August smokeimpacted period.

Similar to CO, ethane has an atmospheric lifetime of the order of a month during summertime at mid-latitudes (Rudolph and Ehhalt, 1981) and is emitted by wildfires (Akagi et al., 2011). However, average ethane mixing ratios were not higher during the August smoke-impacted period compared to the smoke-free period. One potential reason for this may be the large local sources of alkanes from oil and natural gas activities within the Denver-Julesberg Basin which contribute to relatively high local mixing ratios of these species (Gilman et al., 2013; Swarthout et al., 2013; Thompson et al., 2014; Abeleira et al., 2017). The range of ethane mixing ratios observed at BAO was also not different between smoke-free (0.3-337 ppbv) and smoke-impacted periods (1-362 ppbv). Similarly, we did not observe significant changes in most of the $\mathrm{C}_{3}-\mathrm{C}_{9}$ alkanes we measured. Figure 3 shows there were two exceptions to the general alkane observations: 2-methylhexane showed a significant decrease in average abundances $(-39$ pptv or $-45 \%)$ and 3-methylhexane showed a significant increase
(63 pptv or $75 \%$ ) during the smoke-impacted period, despite both having similar smoke-free abundances and similar rate constants for reaction with the hydroxyl radical $\left(\mathrm{OH} ; k_{\mathrm{OH}}\right.$ $\sim 7 \times 10^{12} \mathrm{~cm}^{3} \mathrm{molec}^{-1} \mathrm{~s}^{-1}$ ).

The atmospheric lifetimes of the four alkenes we quantified (isoprene, propene, ethene, and cis-2-butene) range from tens of minutes to hours. Surprisingly, we observed significant decreases in the abundance of isoprene, propene and ethene during the August smoke-impacted period compared to the smoke-free period: $-64 \%$ (-143 pptv), $-77 \%$ $(-39 \mathrm{pptv})$, and $-81 \%(-206 \mathrm{pptv})$ respectively (for summary statistics see Table 1). The shape of the diurnal cycles did not change (Fig. S2), though propene and ethene were near their respective limits of detection for the majority of each day during the smoke-impacted period. Given the short lifetimes of these species, this indicates that the presence of the smoke changed either local anthropogenic or biogenic emissions of these species, or their respective rates of oxidation by $\mathrm{OH}$ or $\mathrm{O}_{3}$. We present several potential mechanisms here, but we do not have sufficient information to determine whether one of these is solely responsible for the pattern we observed.

Our first hypothesis is that fewer anthropogenic emissions of these alkenes drove the observed decreases in alkene abundances. However, there is no evidence that anthropogenic emissions were different during the August smoke-impacted period. Specifically, the August smoke-impacted period encompassed both weekdays and weekends and did not contain any state or federal holidays. Therefore we move to our second hypothesis, that changes in the biogenic emissions of alkenes accounted for the decreased alkene mixing ratios. Isoprene is widely known to be emitted by broad leaf vegetation, and emission rates are positively correlated with light and temperature (Guenther et al., 2006). Recent measurements quantified ethene and propene emissions from a ponderosa pine forest near Colorado Springs, CO, with an interdaily light and temperature dependence similar to isoprene (Rhew et al., 2017). Interestingly, emissions and mixing ratios of ethene and propene were not closely correlated with isoprene within the diurnal cycle, indicating they have different vegetative/soil sources than isoprene at that site. Ponderosa pine stands are present in the foothills on the western edge of the plains in the Front Range, and several species of broad leaf trees are present along waterways, in urban areas, and in the foothills of this region. Thus, biogenic sources of ethene, propene, and isoprene in the region around $\mathrm{BAO}$ are reasonable. Given the August smoke-impacted period was on average colder than the smoke-free period, and potentially saw a reduction in photosynthetic active radiation (PAR) at the surface due to the increased number of aerosols, it is possible that biogenic emissions of isoprene, ethene, and propene were suppressed. However, biogenic fluxes of these compounds are unavailable for the region around BAO during summer 2015, and extrapolating emissions from one ponderosa pine stand to the rest of the Front Range may be overly 
Table 1. Summary of alkene statistics at the Boulder Atmospheric Observatory during the smoke-free period and the August smoke-impacted period in summer 2015.

\begin{tabular}{lrrrr|rrrrr}
\hline & \multicolumn{4}{c}{ Smoke-free period } & \multicolumn{4}{c}{ August smoke-impacted period } \\
\cline { 2 - 9 } Compound & min & median & $\operatorname{mean}^{\mathrm{a}}$ & $\max$ & $\min$ & median & $\operatorname{mean}^{\mathrm{a}}$ & $\max$ \\
\hline ethene $^{\mathrm{b}}$ & 0.001 & 0.2 & $0.253(0.212)$ & 1.94 & 0.001 & 0.001 & $0.0464(0.128)$ & 0.918 \\
propene $^{\mathrm{b}}$ & 0.002 & 0.041 & $0.051(0.04)$ & 0.41 & 0.002 & 0.008 & $0.011(0.012)$ & 0.086 \\
cis-2-butene & 0.001 & 0.018 & $0.0236(0.0292)$ & 0.345 & 0.001 & 0.014 & $0.023(0.07)$ & 1.08 \\
isoprene $^{\mathrm{b}}$ & 0.003 & 0.141 & $0.223(0.268)$ & 2.02 & 0.001 & 0.048 & $0.0804(0.114)$ & 1.16 \\
\hline
\end{tabular}

a Standard deviation in parentheses. ${ }^{\mathrm{b}}$ Indicates statistically significant change in mean during August smoke-impacted period as compared to the smoke-free period.

ambitious. Further, we note that a positive matrix factorization analysis of the VOC data from this site did produce a "biogenic factor" dominated by isoprene, but with negligible contribution of any other hydrocarbon, suggesting that the biogenic component of these $\mathrm{C}_{2}-\mathrm{C}_{3}$ alkenes was small (Abeleira et al., 2017). Thus, while the hypothesis that smoke suppressed biogenic emissions remains feasible, we consider other potential causes for the observed decrease in alkene abundances below.

The alkenes we measured all have high reactivities with respect to $\mathrm{OH}\left(>8 \times 10^{12} \mathrm{molec}^{-1} \mathrm{~cm}^{3} \mathrm{~s}\right)$ and $\mathrm{O}_{3}$ $\left(>0.1 \times 10^{17} \mathrm{molec}^{-1} \mathrm{~cm}^{3} \mathrm{~s}\right.$; Atkinson and Arey, 2003). Enhancements in $\mathrm{OH}$ abundances have been inferred in wildfire smoke plumes by several studies (e.g., Akagi et al., 2012; Hobbs et al., 2003; Liu et al., 2016; Yokelson et al., 2009). If the August smoke-impacted period was characterized by higher than normal $\mathrm{OH}$ mixing ratios, then a third hypothesis is that the observed decreases in alkene abundances could be due to a higher oxidation rate by $\mathrm{OH}$ due to higher $\mathrm{OH}$ concentrations. However, other measured VOCs such as $O$ xylene or methylcyclohexane have similar $\mathrm{OH}$ reactivities to ethene (Atkinson and Arey, 2003), and we do not see associated decreases in abundances of these other VOCs. Thus, the hypothesis of increased oxidation by $\mathrm{OH}$ causing decreased alkene abundances in the August smoke period is not supported by the full suite of measurements at BAO.

Lastly, we move on to our final hypothesis. Alkenes have much higher rates of reaction with $\mathrm{O}_{3}$ than the other VOCs we quantified. As we will demonstrate in Sect. 4.3, the August smoke-impacted period was characterized by higher $\mathrm{O}_{3}$ abundances than would otherwise be expected. Therefore, the fourth hypothesis regarding decreased alkene abundances is that enhanced alkene oxidation by $\mathrm{O}_{3}$ decreased the observed mixing ratios. Two factors complicate this hypothesis though. First, we do not observe a negative relationship between $\mathrm{O}_{3}$ and alkene abundance during the smoke-free time periods (i.e., increased $\mathrm{O}_{3}$ is not correlated with decreased alkenes when no smoke is present). Second, despite having a higher reaction rate with $\mathrm{O}_{3}$ compared to propene and ethene, cis-2-butene does not decrease during the August smokeimpacted period.
After careful consideration, there is no strong evidence supporting any of these four hypotheses over the others (suppressed anthropogenic emissions, suppressed biogenic emissions, increased $\mathrm{OH}$, increased $\mathrm{O}_{3}$ ). It is possible that more than one of these processes could have contributed to the observation of decreased alkene abundances during the 2-weeklong August smoke-influenced period. Future field campaigns and modeling work are necessary to understand how common suppressed alkene abundances may be in smokeimpacted air masses, and what processes might control this phenomenon.

The only alkyne measured was ethyne. Ethyne is emitted by wildfires (Akagi et al., 2011) and has a lifetime of $\sim 1$ month during summer. We observed a significant increase in the abundance of ethyne during the August smokeimpacted period. These enhancements were small in absolute mixing ratio $(0.163 \mathrm{ppbv})$, but represented a large percentage increase $(67 \%)$ and were consistently present throughout the day.

It is well known that wildfires produce carcinogenic aromatic hydrocarbons including benzene (Fent et al., 2014). During the smoke-impacted periods, we observed significantly enhanced benzene throughout the day with an average increase of $0.117 \mathrm{ppbv}$ and a percentage increase of $67 \%$. These enhancements followed the pattern of $\mathrm{CO}$ and ethyne; there were consistent increases throughout the day and the diurnal cycle retained its shape. Wildfires also produce toluene (Fent et al., 2014); however, it has a substantially shorter lifetime ( $<2$ days) than benzene $(\sim 12$ days). Toluene showed no significant changes in its mean mixing ratio, diurnal cycle, or range of values measured at $\mathrm{BAO}$ during the smoke-impacted periods. The other aromatic hydrocarbons we quantified (oxylene and ethyl benzene) also did not change significantly.

As mentioned in Sect. 1, oxygenated VOCs are emitted by wildfires and make a large contribution to the total emitted VOC mass in wildfire smoke (Stockwell et al., 2015). Additionally they are produced as oxidation intermediates (Atkinson and Arey, 2003). Acetaldehyde, acetone, and methyl ethyl ketone (MEK) showed no consistent changes in their abundances, diurnal cycles, or range during the smoke-impacted period compared to the smoke-free 
period. Small increases in average acetone $(\sim 350 \mathrm{pptv})$ and MEK ( $\sim 150$ pptv) mixing ratios during late afternoon and evening hours were not statistically significant.

Given the diversity of emission sources across the northern Colorado Front Range, previous studies of atmospheric composition at $\mathrm{BAO}$ have noted a strong dependence of VOC composition on wind direction (Pétron et al., 2012; Gilman et al., 2013). Recent housing development and oil and gas production surrounding the BAO site have made analyses based on wind direction more challenging in recent years (McDuffie et al., 2016). Importantly for our analysis, we found that the statistically significant changes in all species during the smoke-impacted periods occurred across all wind directions. Figure 4 shows this for two representative species: benzene and $\mathrm{NO}_{2}$. We also did not find statistically significant changes in wind direction or wind speed patterns between smoke-free and smoke-impacted periods. Thus, we attribute the changes in atmospheric composition during the August smoke-impacted period to the presence of smoke.

\subsection{Reactive oxidized nitrogen $\left(\mathrm{NO}_{y}\right)$ species}

Peroxyacyl nitrates and $\mathrm{HNO}_{3}$ were successfully measured from 10 July to 7 September and alkyl nitrates were measured from 24 July to 30 August. Thus we report significant changes in these species for the August smoke-impacted period only. We observed significant enhancements in both peroxyacetyl nitrate (PAN) and peroxypropionyl nitrate (PPN) during the August smoke-impacted period. PAN and PPN abundances were consistently elevated across the day by an average of 183 and 22 pptv respectively, corresponding to a $\sim 100 \%$ change for both species. The peak of each diurnal cycle was shifted later in the day by about $3-4 \mathrm{~h}$ for the smoke-impacted period. This cannot be accounted for merely by the shift in the timing of solar noon given that the total decrease in daylight between 10 July and 30 August is $\sim 2 \mathrm{~h}$. The $\mathrm{C}_{1}-\mathrm{C}_{2}$ alkyl nitrates measured at BAO exhibited similar behaviors; methyl nitrate and ethyl nitrate saw average enhancements during the August smoke period of 1.2 and 0.77 pptv, 41 and $31 \%$ respectively, though the average mixing ratios of these species are smaller by an order of magnitude compared to other alkyl nitrates quantified. Propyl, pentyl, and butyl nitrate did not display significant changes in their average mixing ratio, though we observed a similar shift in the peak of their diurnal cycles of $2-4 \mathrm{~h}$. We did not observe significant changes in the abundances of $\mathrm{HNO}_{3}$. There were no changes to the diurnal cycle of $\mathrm{HNO}_{3}$ or the range of mixing ratios observed.

$\mathrm{NO}$ and $\mathrm{NO}_{2}$ measurements were made during the entire campaign, 1 July-7 September 2015, so both the July and August smoke-impacted periods were analyzed with respect to potential changes in $\mathrm{NO}_{x}$. $\mathrm{NO}$ was present in the same abundances between the two periods and showed the same diurnal cycle during the August smoke-impacted period as compared to the smoke-free period (Fig. 5). During the July smoke-impacted period the morning build-up of NO was slower than the smoke-free period, though the mixing ratios were within the range of smoke-free values and the duration of the July smoke-impacted period was much shorter than the August smoke-impacted period.

Figure 5 shows that $\mathrm{NO}_{2}$ abundances exhibited more significant changes than NO. During the July smoke-impacted period, $\mathrm{NO}_{2}$ was within the range of smoke-free measurements. In contrast $\mathrm{NO}_{2}$ during the August smoke-impacted period followed the same diurnal cycle but had pronounced significant increases in average mixing ratios during the morning and evening hours of $\sim 8 \mathrm{ppbv}$ (17\%) following sunrise and $3 \mathrm{ppbv}(60 \%)$ following sunset. These enhanced peak abundances appeared during multiple days during the August smoke-impacted period. Out of seven morning peaks in $\mathrm{NO}_{2}$ during the August smoke-impacted period, three had concurrent toluene and ethyne peaks. One of these days occurred on a weekend, and the others occurred on weekdays. Toluene and ethyne are common tracers of traffic/industrial emissions. However, four of the days did not have corresponding ethyne and toluene peaks. Thus, we cannot rule out that traffic did not impact some of the $\mathrm{NO}_{2}$ enhancements we observed. But there is also likely another contributing mechanism. There are a few potential hypotheses for a non-traffic related $\mathrm{NO}_{2}$ enhancement during the August smoke period. One hypothesis is that the photolysis frequency $\left(\mathrm{N}_{\mathrm{NO}_{2}}\right)$ was most impacted (i.e., reduced) by the smoke near sunrise and sunset. Another hypothesis concerns the equilibrium between PAN and $\mathrm{NO}_{2}$. The thermal decomposition of PAN can be a source of $\mathrm{NO}_{2}$ (Singh and Hanst, 1981), but the concurrently observed PAN abundances during the August smoke-impacted period can only account for at most $1 \mathrm{ppbv}$ of additional $\mathrm{NO}_{2}$. However, there could have been significantly higher PAN abundances in the smoke plume prior to reaching BAO so this hypothesis for the $\mathrm{NO}_{2}$ enhancements cannot be fully ruled out. We do not have measurements of other reactive nitrogen species (e.g., $\mathrm{HONO}, \mathrm{ClNO}_{2}, \mathrm{NO}_{3}$, and $\mathrm{N}_{2} \mathrm{O}_{5}$ ) to test other potential hypotheses for a different chemical mechanism to explain the observed $\mathrm{NO}_{2}$ enhancements.

\subsection{Ozone}

As discussed in the Introduction, wildfire smoke has been found to produce $\mathrm{O}_{3}$ within plumes and to be correlated with enhanced surface $\mathrm{O}_{3}$ in areas to which it is advected. The total amount of $\mathrm{O}_{3}$ at a location is a complex combination of the relative abundances of VOCs and $\mathrm{NO}_{x}$, meteorological conditions supporting local $\mathrm{O}_{3}$ production, and the amount of $\mathrm{O}_{3}$ present in the air mass before local production. In this section, we describe the significant increases in $\mathrm{O}_{3}$ during both smoke-impacted periods, show that these enhancements were most likely not due to changes in meteorological conditions, and discuss evidence pointing to whether these changes may 


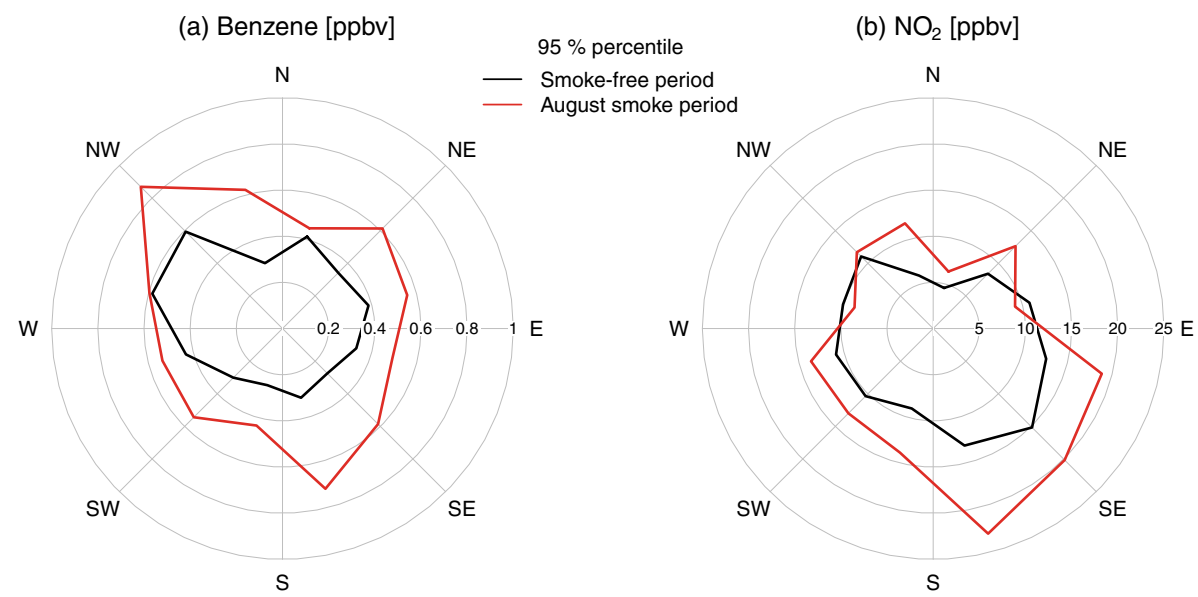

Figure 4. 95th percentiles of all hourly average measurements of (a) benzene and (b) $\mathrm{NO}_{2}$ during the smoke-free period (in black) and the August smoke-impacted period (in red), as a function of wind direction.

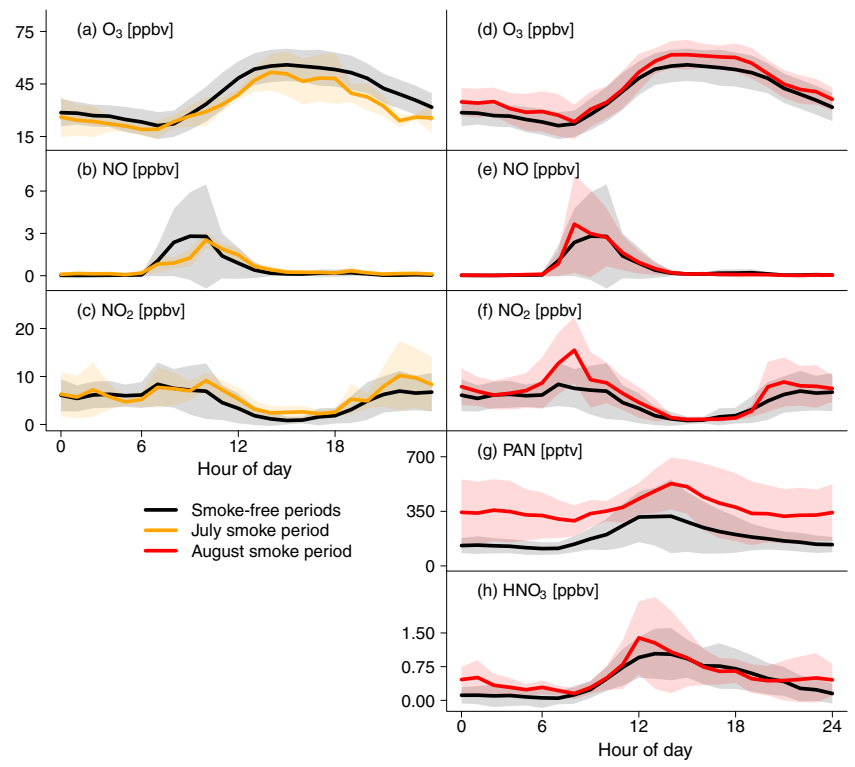

Figure 5. Average diurnal cycles in MDT of $\mathrm{O}_{3}$ and oxidized reactive nitrogen species at BAO. Panels (a), (b), and (c) compare average diurnal cycles from smoke-free time periods (black) to average diurnal cycles from the July smoke-impacted period (orange). Panels (d)-(h) show average diurnal cycles during the August smoke-impacted period (red) to the same average diurnal cycles from smoke-free periods (black). Gray, orange, and red shading indicates plus and minus 1 standard deviation. PAN and $\mathrm{HNO}_{3}$ measurements were not available during the July smoke-impacted period. Solar noon on 1 July 2015 was at 13:03, solar noon on 7 September was 2015 was at 12:57.

be due to enhanced local production or transport of $\mathrm{O}_{3}$ produced within the smoke plume.

Figure $5 \mathrm{~d}$ shows that there were significant increases in $\mathrm{O}_{3}$ mixing ratios during nighttime and midday during the August smoke-impacted period compared to the average smoke- free diurnal cycle. The mean $\mathrm{O}_{3}$ mixing ratio across all hours of the day was $6 \mathrm{ppbv}(14 \%)$ larger during the August smoke-impacted period than the smoke-free period (Fig. 6), significant at the $99 \%$ confidence level based on a twosample difference of means $t$ test. There were no significant changes in the average $\mathrm{O}_{3}$ mixing ratios during the July smoke-impacted period (Fig. 5a). The average mixing ratio of $\mathrm{O}_{3}$ during the July smoke-impacted period was not greater than absolute average during the smoke-free period (Fig. 5a). However, as discussed in Sect. 2, this period in particular was much colder on average than the smoke-free period.

$\mathrm{O}_{3}$ mixing ratios generally increase with temperature, and this relationship has been attributed to several specific processes including (1) warm and often stagnant anti-cyclonic atmospheric conditions that are conducive to $\mathrm{O}_{3}$ formation, (2) warmer air temperatures that reduce the lifetime of PAN, releasing $\mathrm{NO}_{2}$, and (3) lower relative humidity that reduces the speed of termination reactions to the $\mathrm{O}_{3}$ production cycle (Jacob et al., 1993; Camalier et al., 2007). Specific to the Front Range, Abeleira and Farmer (2017) show that ozone in this region has a temperature dependence, but it is smaller than other US regions, consistent with the smaller local biogenic VOC emissions compared to many other locations in the eastern US. Finally, there is an additional meteorological factor in the Front Range that can impact the temperature dependence of ozone. Gusty westerly winds are often associated with high temperatures, and these winds serve to weaken or eliminate cyclical terrain-driven circulations that normally enhance $\mathrm{O}_{3}$ mixing ratios across the Front Range. Figure 6 presents hourly average $\mathrm{O}_{3}$ and temperature at BAO and shows a positive relationship between $\mathrm{O}_{3}$ and temperature for both the smoke-free period and August smokeimpacted period. The increase in $\mathrm{O}_{3}$ mixing ratios during the August smoke-impacted period compared to the smokefree period is present across the entire range of comparable temperatures. The same result is apparent during the July 


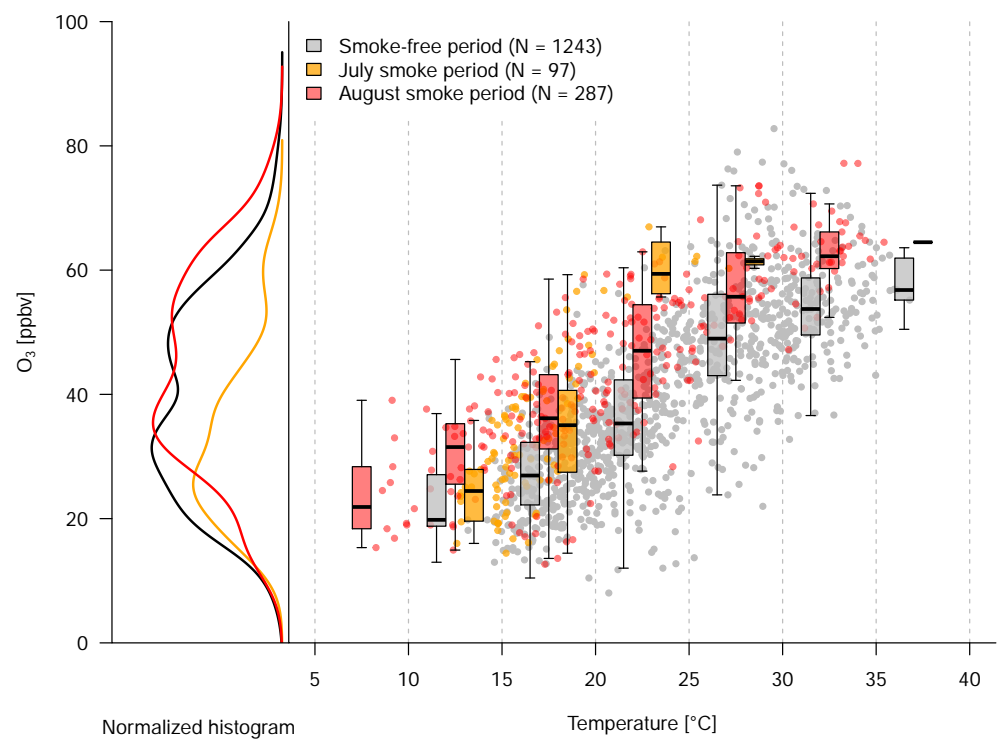

Figure 6. Hourly $\mathrm{O}_{3}$ data from $\mathrm{BAO}$ plotted against hourly temperature data show a positive correlation between temperature and $\mathrm{O}_{3}$ abundances for the smoke-free time periods in gray and both smoke-impacted periods (July in orange and August in red). Overlaid are box plots $\left(5\right.$ th, 25th, 50th, 75th, and 95th percentiles) for each $5^{\circ} \mathrm{C}$ bin. On the left normalized histograms of the hourly $\mathrm{O}_{3}$ data are plotted, with all smoke-free measurements in black, and all hourly measurements made during the July smoke-impacted period in orange, and August smoke-impacted period in red.

smoke period, where, for comparable temperatures, the July smoke period has higher $\mathrm{O}_{3}$ than would be expected from the $\mathrm{O}_{3}$-temperature relationship during the smoke-free period. Across both smoke-impacted periods and for a given temperature, the magnitude of the increase in average $\mathrm{O}_{3}$ was $10 \pm 2$ ppbv. This was calculated as the mean difference between medians within each temperature bin weighted by the total number of hourly measurements within each bin. The weighted standard deviation was calculated in the same way. The magnitude of this difference is greater than the average difference in means between the smoke-free $\mathrm{O}_{3}$ mixing ratios and the August smoke-impacted period because there were several periods during the July and August smokeimpacted period where air temperatures were colder $\left(\sim 5^{\circ} \mathrm{C}\right)$ than most observations during the smoke-free period. Thus the lower $\mathrm{O}_{3}$ mixing ratios associated with these smokeimpacted periods (e.g., $\sim 20-40 \mathrm{ppbv}$ ) were not included in the weighted difference in medians since there were not commensurate smoke-free $\mathrm{O}_{3}$ measurements at those same temperatures.

In addition to a positive relationship with surface temperature, elevated $\mathrm{O}_{3}$ in the western US has also been found to be correlated with monthly average $500 \mathrm{hPa}$ geopotential heights, $700 \mathrm{hPa}$ temperatures, and surface wind speeds on an interannual basis (Reddy and Pfister, 2016). We tested the day-to-day variability in the relationship between $\mathrm{O}_{3}$ and these meteorological variables during our study period using observations from the $0 \mathrm{Z}$ and $12 \mathrm{Z}$ atmospheric soundings conducted in Denver (http://mesonet.agron.iastate.edu/ archive/raob/). The positive relationships between MDA8 $\mathrm{O}_{3}$ and $700 \mathrm{mb}$ temperature, $500 \mathrm{mb}$ geopotential height, and surface winds are very weak $-R^{2}=0.04, R^{2}=0.08$, and $R^{2}=0.0009$ respectively. Thus, we did not find any evidence to support the hypothesis that differences in meteorological conditions were solely responsible for the significant differences in composition or $\mathrm{O}_{3}$ that we observed during the smoke-impacted period.

To determine if a change in synoptic-scale transport in smoke-impacted versus smoke-free periods could have contributed to different abundances, we performed a $k$-means cluster analysis on $72 \mathrm{~h}$ HYSPLIT back trajectories. The trajectories were calculated using the methods described above, and initiated each hour at $2000 \mathrm{~m}$ a.g.l. from BAO. We chose to initialize the trajectories at $2000 \mathrm{~m}$ a.g.l. so that fewer trajectories intersect the ground in the Rocky Mountains. Trajectories are unlikely to capture the complex circulations (e.g., potential Denver cyclones or up/down slope winds) characteristic of summertime in the Front Range, but they should capture synoptic-scale air mass motions. The $k$-means analysis clustered each trajectory into a predetermined number of clusters by minimizing the distance between each trajectory and its nearest neighbor; this technique has been used to classify air mass history in air quality studies (Moody et al., 1998). We found four predominate trajectory clusters during our study period: northwesterly flow, westerly flow, southwesterly flow, and local/indeterminate flow (Fig. S3). We then compared afternoon (12:00-17:00 MDT) hourly $\mathrm{O}_{3}$ measurements separated by trajectory cluster and binned by temperature between the smoke-free period and the $\mathrm{Au}$ gust smoke-impacted period. Most hours during the August 


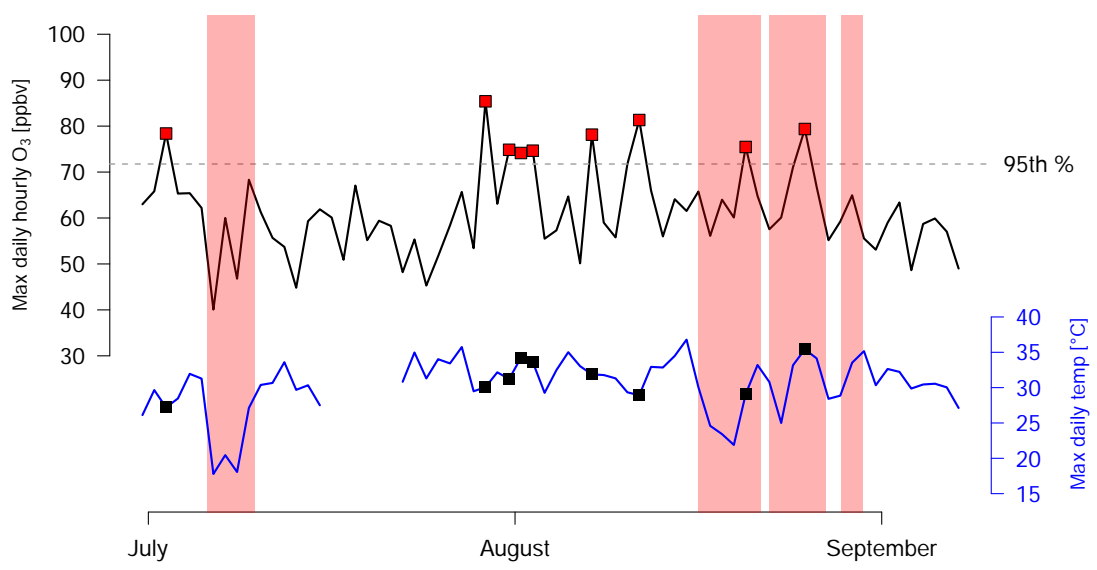

Figure 7. Maximum hourly average $\mathrm{O}_{3}$ mixing ratios for each day at BAO plotted in black with maximum daily temperature at BAO in blue. Red boxes denote days that exceed the 95th percentile of all hourly average $\mathrm{O}_{3}$ mixing ratios between 11:00 and 16:00 MDT. Black boxes pinpoint these same days in the temperature time series.

smoke-impacted period were associated with northwesterly flow and we found a similar enhancement in $\mathrm{O}_{3}$ for a given temperature when comparing smoke-impacted observations to smoke-free observations assigned to this cluster as we found for the complete dataset (Figs. S4 and S5). Thus we conclude that potential changes in $\mathrm{O}_{3}$ driven by synopticscale transport conditions cannot account for the observed $\mathrm{O}_{3}$ enhancements during the August smoke-impacted period at $\mathrm{BAO}$.

Following the definition in Cooper et al. (2012), we define a "high- $\mathrm{O}_{3}$ day" as any day in our study period with at least $1 \mathrm{~h}$ above the 95 th percentile $(71.75 \mathrm{ppbv})$ of all 11:00-16:00 MDT hourly average $\mathrm{O}_{3}$ measurements during the campaign. We found 9 individual high- $\mathrm{O}_{3}$ days during our study period, of which 2 occurred during the August smoke-impacted period (Fig. 7). The total number of high$\mathrm{O}_{3}$ days is lower than normal for the same time period in previous years. As we stated above, high $\mathrm{O}_{3}$ during the $\mathrm{Au}-$ gust smoke period was not a result of abnormal meteorological variables, such as higher than normal temperatures. The lower portion of Fig. 7 again shows that maximum daily temperatures during the smoke-impacted periods were the same as or lower than maximum daily temperatures during the smoke-free period. Denver cyclones and in-basin wind patterns can also contribute to $\mathrm{O}_{3}$ production and recirculation in the Front Range (see Sullivan et al., 2016; Vu et al., 2016, and references within). We examined surface wind observations (http://mesowest.utah.edu) on the 2 high- $\mathrm{O}_{3}$ days during the smoke impacted period: 20 August and 25 August. There is no evidence of the establishment of Denver cyclones on either of these days. Sullivan et al. (2016) point out that thermally driven recirculation can manifest as a secondary increase in $\mathrm{O}_{3}$ at surface sites. We did observe a secondary maximum at 17:00 MDT on 25 August, but this feature was not present on 20 August.
Several Front Range $\mathrm{O}_{3}$ monitors recorded elevated ozone during the August smoke-impacted period. Specifically, the maximum daily $8 \mathrm{~h}$ average $\mathrm{O}_{3}$ mixing ratio at Aurora East exceeded 75 ppbv on 21 August. This was the highest maximum for this station for summer 2015. The second highest maximum for summer 2015 coincided with the August smoke-impacted period at Fort Collins West, Greely, La Casa, Welby, and Aurora East. The third highest maximum for summer 2015 coincided with the August smoke-impacted period at Aurora East, South Boulder Creek, Rocky Mountain National Park, and Fort Collins - CSU.

The presence of smoke was not always associated with high absolute abundances of $\mathrm{O}_{3}$ at BAO. The July smokeimpacted period and most of the days in the August smoke period did not have maximum hourly mixing ratios greater than the 95th percentile. However, it is important to note that many of these days did have higher $\mathrm{O}_{3}$ abundances than would otherwise be expected given their temperatures (see Fig. 6). Therefore we conclude that the presence of wildfire smoke contributed to higher $\mathrm{O}_{3}$ mixing ratios than would otherwise be expected during the two smoke events we sampled, and that during 2 of these days the smoke contributed to an empirically defined "high- $\mathrm{O}_{3}$ day".

As mentioned in the Introduction, wildfire smoke can produce $\mathrm{O}_{3}$ within the plume as it is transported, as well as contribute to $\mathrm{O}_{3}$ photochemistry by mixing additional precursors into surface air masses. To assess the possibility of $\mathrm{O}_{3}$ production with the plume, we analyzed hourly $\mathrm{O}_{3}$ measurements from two National Park Service (NPS) Air Resources Division (http://ard-request.air-resource.com/data. aspx) measurement locations that are located outside the polluted Front Range urban corridor. The Rocky Mountain National Park long-term monitoring site (ROMO; $40.2778^{\circ} \mathrm{N}$, $105.5453^{\circ} \mathrm{W} ; 2743 \mathrm{~m}$ a.s.l.) is located on the east side of the Continental Divide and co-located with the Interagency Monitoring of Protected Visual Environments (IMPROVE) 

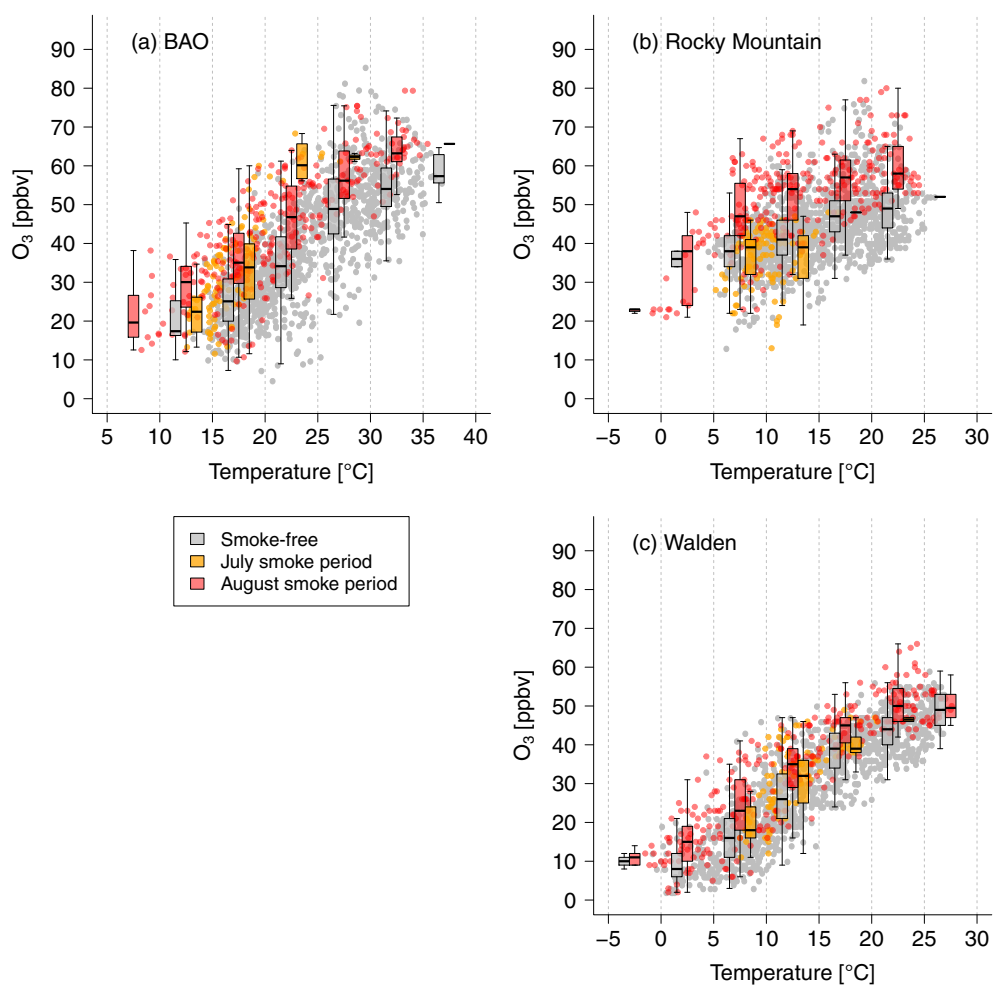

Figure 8. Hourly $\mathrm{O}_{3}$ versus temperature for (a) BAO, (b) the Rocky Mountain National Park long-term monitoring site (ROMO), and (c) the Arapahoe National Wildlife Refuge long-term monitoring site near Walden, CO (WALD). Plotted here are all hourly data, with box plots showing standard percentiles of $5^{\circ} \mathrm{C}$ binned $\mathrm{O}_{3}$ data as shown in Fig. 6.

and EPA Clean Air Status and Trends Network (CASTNet) monitoring sites. Front Range air masses frequently reach this site during summer afternoons (Benedict et al., 2013). The Arapahoe National Wildlife Refuge long-term monitoring site (WALD; $40.8822^{\circ} \mathrm{N}, 106.3061^{\circ} \mathrm{W} ; 2417 \mathrm{~m}$ a.s.l.) near Walden, Colorado, is a rural mountain valley site with very little influence from anthropogenic emissions. These two sites follow a rough urban to rural gradient; from primarily influenced by anthropogenic emissions (BAO), to sometimes influenced by anthropogenic emissions (ROMO), to very little influence from anthropogenic emissions (WALD). Figure 8 shows that the August smoke-impacted period produced increases in $\mathrm{O}_{3}$ mixing ratios across all three sites. When comparing all data for a given temperature, there are average weighted enhancements of $10 \pm 2,10 \pm 2$, and $6 \pm 2 \mathrm{ppbv}_{3}$ at BAO, ROMO, and WALD respectively. $\mathrm{O}_{3}$ enhancements across all three sites, across an approximate urban to rural gradient, suggest that some amount of the $\mathrm{O}_{3}$ enhancement observed at BAO during the August smokeimpacted period is the result of $\mathrm{O}_{3}$ production within the plume during transit. $\mathrm{O}_{3}$ during the July smoke-impacted period in Fig. 8 shows a different pattern. As we saw in Fig. 6, $\mathrm{O}_{3}$ is enhanced above the level predicted by the ambient temperature at BAO. But no statistically significant enhancements are observed at ROMO and WALD for the July smoke- impacted period. One possible reason for this nuance is that, based on the HMS smoke product shown in Fig. 2, it is less obvious that smoke was present at ROMO and WALD during the July smoke-impacted period.

One measure of local production of $\mathrm{O}_{3}$ is the ozone production efficiency (OPE). OPE is calculated as the slope of the relationship between $\mathrm{O}_{3}$ and $\mathrm{NO}_{z}$ (defined as $\mathrm{NO}_{y}$ $\mathrm{NO}_{x}$; Trainer et al., 1993). OPE is a measure of the number of molecules of $\mathrm{O}_{3}$ that are produced before a given $\mathrm{NO}_{x}$ molecule is oxidized. To calculate OPE we used $1 \mathrm{~min} \mathrm{O}_{3}$ and $\mathrm{NO}_{z}$ data in 30 min chunks from 12:00 to 17:00 MDT. The slopes were calculated using a reduced major axis regression (package lmodel 2 for $\mathrm{R}$ software) and only OPE values corresponding to an $R^{2}>0.3$ were retained. We do not find any significant differences in average calculated OPE between the smoke-impacted $\left(8 \pm 3 \mathrm{ppbv}_{\mathrm{ppbv}}{ }^{-1}\right)$ and smokefree periods $\left(7 \pm 3 \mathrm{ppbv}_{\mathrm{ppbv}}{ }^{-1}\right)$. Thus from the OPE perspective it does not appear there were any changes in the local production efficiency of $\mathrm{O}_{3}$ due to the presence of smoke. On the other hand, we documented many changes to the atmospheric composition of $\mathrm{O}_{3}$ precursors, particularly with respect to $\mathrm{CO}$, benzene, ethyne, the alkenes, and PANs. Additionally the smoke may have added many $\mathrm{O}_{3}$ precursors that we were not set up to measure (e.g., many OVOCs). Due to the nonlinear nature of $\mathrm{O}_{3}$ chemistry, the different 
mix of precursors could have caused enhanced local $\mathrm{O}_{3}$ production, depressed local $\mathrm{O}_{3}$ production, or had no effect on local $\mathrm{O}_{3}$ production. Taken together, the observations do not suggest a single mechanism that describes smoke influence on $\mathrm{O}_{3}$ in Front Range air masses during these case studies. Instead, the observations point to the presence of smoke resulting in a complex array of processes that will require more detailed observations and chemical transport modeling to clearly identify and quantify.

\section{Conclusions}

Here we report a time series of detailed gas-phase ground measurements in the northern Colorado Front Range during summer 2015. Clear anomalies in $\mathrm{CO}$ and $\mathrm{PM}_{2.5}$ showed that aged wildfire smoke was present at ground-level during two distinct periods (6-10 July and 16-30 August) for a total of nearly three out of the nine weeks sampled. This smoke from wildfires in the Pacific Northwest and Canada impacted a large area across much of the central and western US, and was several days old when it was sampled in Colorado. This wildfire smoke mixed with anthropogenic emissions in the Front Range, resulting in significant changes in the abundances of $\mathrm{O}_{3}$ and many of its precursor species. Our measurements are unique because of (1) the length of time we sampled this smoke-impacted anthropogenic air mass, and (2) the detailed composition information that was collected.

During the smoke-impacted periods we observed significantly increased abundances of $\mathrm{CO}, \mathrm{CH}_{4}$, and several VOCs with $\mathrm{OH}$ oxidation lifetimes longer than the transport time of the smoke. We measured significant decreases in several of the most reactive alkene species, indicating possible enhanced oxidation processes occurring locally. Mixing ratios of peroxyacyl nitrates and some alkyl nitrates were enhanced and peak abundances were delayed by $3-4 \mathrm{~h}$, but there was no significant change in $\mathrm{HNO}_{3}$ mixing ratios or its diurnal cycle. During the longer August smoke-impacted period we observed significant increases in $\mathrm{NO}_{2}$ mixing ratios just after sunrise and sunset. We did not observe any consistent shifts in wind direction or changes in wind speed that can explain the observed changes in composition (e.g., Fig. 4), and the changes in abundances that we observed for a given species were generally present across all directions and speeds. The smoke was ubiquitous across the Front Range as evidenced by enhanced $\mathrm{PM}_{2.5}$ at CAMP (Fig. 1) and 9 other Front Range CDPHE monitoring sites.

We observed significantly enhanced $\mathrm{O}_{3}$ abundances at $\mathrm{BAO}$ of about $10 \mathrm{ppbv}$ for a given temperature during both smoke-impacted periods. The enhancements during the August smoke-period led to very high surface $\mathrm{O}_{3}$ levels on several days; out of nine high- $\mathrm{O}_{3}$ days at $\mathrm{BAO}$ during our study period, two were during the August smoke-impacted period. These enhancements were not due to higher temperatures, nor anomalous meteorological conditions. We found evidence of $\mathrm{O}_{3}$ produced within the smoke plume during transit, and changes in the observed abundances of many $\mathrm{O}_{3}$ precursors indicated that the smoke may have impacted local $\mathrm{O}_{3}$ production as well. Future modeling work and additional observational studies are needed in order to fully address the question of how much $\mathrm{O}_{3}$ the smoke produced and how it changed local $\mathrm{O}_{3}$ production.

It is important to note that the presence of smoke does not always result in very high $\mathrm{O}_{3}$ abundances. Many other factors contribute to the overall level of surface $\mathrm{O}_{3}$, and smoke can also be associated with relatively low $\mathrm{O}_{3}$ at times, such as during the July smoke event described above. This case study describes two distinct smoke events where the presence of smoke likely increased $\mathrm{O}_{3}$ abundances above those expected by coincident temperatures. However, we do not intend to claim that all high- $\mathrm{O}_{3}$ episodes in the Front Range are caused by smoke, nor that smoke will always cause higher than expected $\mathrm{O}_{3}$. Each smoke event has unique characteristics and thus it is important to study and characterize more events such as these in the future.

Wildfire smoke during these time periods in 2015 most likely impacted atmospheric composition and photochemistry across much of the Mountain West and Great Plains regions of the US. Given that the BAO, Rocky Mountain, and Walden research locations span an urban-rural gradient as well as a large altitudinal gradient, it is likely that both rural and urban locations impacted by this smoke could have experienced enhanced $\mathrm{O}_{3}$ levels. Additionally, the Pacific Northwest wildfires that produced this smoke were among the most extreme in that region's history. We know that wildfires are increasing in both frequency and intensity throughout the western US due to climate change, and thus wildfire smoke events such as this one will likely play an increasingly problematic role in US air quality.

Data availability. Unless otherwise specified, data used in this paper are available at https://esrl.noaa.gov/csd/groups/csd7/ measurements/2015songnex/. NOAA BAO ozone data can be accessed at ftp.cmdl.noaa.gov/data/ozwv/SurfaceOzone/BAO/. National Park Service ozone data can be accessed at https://ard-request.air-resource.com/data.aspx. aspx. Additionally readers may contact Emily Fischer at evf@rams.colostate.edu for data access.

\section{The Supplement related to this article is available online at https://doi.org/10.5194/acp-17-10691-2017- supplement.}

Author contributions. JL compiled and analyzed the data, and wrote the paper. All authors participated in data collection at BAO and contributed to the writing of, or provided comments on, the paper. 
Competing interests. The authors declare that they have no conflict of interest.

Acknowledgements. Funding for this work was provided by the US National Oceanic and Atmospheric Administration (NOAA) under Award number NA14OAR4310148. Support for Jakob Lindaas was provided by the American Meteorological Society Graduate Fellowship. We appreciate all the logistical help at BAO provided by Dan Wolfe, Gerd Hübler, and Bruce Bartram. We appreciate access to NOAA GMD ozone data provided by Audra McClure-Begley. We thank Bill Kotasek and Gordon Pierce at CDPHE for providing access to CDPHE data. Thanks are also due to Jake Zaragoza and Steven Brey for assistance at BAO and for running the HYSPLIT trajectories.

Edited by: Steven Brown

Reviewed by: two anonymous referees

\section{References}

Abeleira, A., Pollack, I. B., Sive, B., Zhou, Y., Fischer, E. V., and Farmer, D. K.: Source Characterization of Volatile Organic Compounds in the Colorado Northern Front Range Metropolitan Area during Spring and Summer 2015, J. Geophys. Res.-Atmos., 122, 3595-3613, https://doi.org/10.1002/2016JD026227, 2017.

Abeleira, A. J. and Farmer, D. K.: Summer ozone in the northern Front Range metropolitan area: weekend-weekday effects, temperature dependences, and the impact of drought, Atmos. Chem. Phys., 17, 6517-6529, https://doi.org/10.5194/acp-176517-2017, 2017.

Akagi, S. K., Yokelson, R. J., Wiedinmyer, C., Alvarado, M. J., Reid, J. S., Karl, T., Crounse, J. D., and Wennberg, P. O.: Emission factors for open and domestic biomass burning for use in atmospheric models, Atmos. Chem. Phys., 11, 4039-4072, https://doi.org/10.5194/acp-11-4039-2011, 2011.

Akagi, S. K., Craven, J. S., Taylor, J. W., McMeeking, G. R., Yokelson, R. J., Burling, I. R., Urbanski, S. P., Wold, C. E., Seinfeld, J. H., Coe, H., Alvarado, M. J., and Weise, D. R.: Evolution of trace gases and particles emitted by a chaparral fire in California, Atmos. Chem. Phys., 12, 1397-1421, https://doi.org/10.5194/acp12-1397-2012, 2012.

Alvarado, M. J., Logan, J. A., Mao, J., Apel, E., Riemer, D., Blake, D., Cohen, R. C., Min, K. E., Perring, A. E., Browne, E. C., Wooldridge, P. J., Diskin, G. S., Sachse, G. W., Fuelberg, H., Sessions, W. R., Harrigan, D. L., Huey, G., Liao, J., CaseHanks, A., Jimenez, J. L., Cubison, M. J., Vay, S. A., Weinheimer, A. J., Knapp, D. J., Montzka, D. D., Flocke, F. M., Pollack, I. B., Wennberg, P. O., Kurten, A., Crounse, J., Clair, J. M. S., Wisthaler, A., Mikoviny, T., Yantosca, R. M., Carouge, C. C., and Le Sager, P.: Nitrogen oxides and PAN in plumes from boreal fires during ARCTAS-B and their impact on ozone: an integrated analysis of aircraft and satellite observations, Atmos. Chem. Phys., 10, 9739-9760, https://doi.org/10.5194/acp10-9739-2010, 2010.

Atkinson, R. and Arey, J.: Atmospheric Degradation of Volatile Organic Compounds, Chem. Rev., 103, 4605-4638, https://doi.org/10.1021/cr0206420, 2003.
Benedict, K. B., Carrico, C. M., Kreidenweis, S. M., Schichtel, B., Malm, W. C., and Collett, J. L.: A seasonal nitrogen deposition budget for Rocky Mountain National Park, Ecol. Appl., 23, 1156-1169, 2013.

Brey, S. J. and Fischer, E. V.: Smoke in the City: How Often and Where Does Smoke Impact Summertime Ozone in the United States?, Environ. Sci. Technol., 50, 1288-1294, https://doi.org/10.1021/acs.est.5b05218, 2016.

Brey, S. J., Ruminski, M., Atwood, S. A., and Fischer, E. V.: Connecting smoke plumes to sources using Hazard Mapping System (HMS) smoke and fire location data over North America, Atmos. Chem. Phys. Discuss., https://doi.org/10.5194/acp-2017-245, in review, 2017.

Camalier, L., Cox, W., and Dolwick, P.: The effects of meteorology on ozone in urban areas and their use in assessing ozone trends, Atmos. Environ., 41, 7127-7137, https://doi.org/10.1016/j.atmosenv.2007.04.061, 2007.

Cooper, O. R., Gao, R.-S., Tarasick, D., Leblanc, T., and Sweeney, C.: Long-term ozone trends at rural ozone monitoring sites across the United States, 1990-2010, J. Geophys. Res.-Atmos., 117, D22307, https://doi.org/10.1029/2012JD018261, 2012.

Creamean, J. M., Neiman, P. J., Coleman, T., Senff, C. J., Kirgis, G., Alvarez, R. J., and Yamamoto, A.: Colorado air quality impacted by long-range-transported aerosol: a set of case studies during the 2015 Pacific Northwest fires, Atmos. Chem. Phys., 16, 1232912345, https://doi.org/10.5194/acp-16-12329-2016, 2016.

Crosson, E. R.: A cavity ring-down analyzer for measuring atmospheric levels of methane, carbon dioxide, and water vapor, Appl. Phys. B, 92, 403-408, https://doi.org/10.1007/s00340-008-3135y, 2008.

Elliott, C., Henderson, S., and Wan, V.: Time series analysis of fine particulate matter and asthma reliever dispensations in populations affected by forest fires, Environ. Health, 12, 1-11, https://doi.org/10.1186/1476-069X-12-11, 2013.

Fent, K. W., Eisenberg, J., Snawder, J., Sammons, D., Pleil, J. D., Stiegel, M. A., Mueller, C., Horn, G. P., and Dalton, J.: Systemic Exposure to PAHs and Benzene in Firefighters Suppressing Controlled Structure Fires, Annals of Occupational Hygiene, 58, 830-845, https://doi.org/10.1093/annhyg/meu036, 2014.

Flocke, F. M., Weinheimer, A. J., Swanson, A. L., Roberts, J. M., Schmitt, R., and Shertz, S.: On the Measurement of PANs by Gas Chromatography and Electron Capture Detection, J. Atmos. Chem., 52, 19-43, https://doi.org/10.1007/s10874-005-6772-0, 2005.

Giglio, L., Descloitres, J., Justice, C. O., and Kaufman, Y. J.: An Enhanced Contextual Fire Detection Algorithm for MODIS, Remote Sens. Environ., 87, 273-282, https://doi.org/10.1016/S0034-4257(03)00184-6, 2003.

Giglio, L., Csiszar, I., and Justice, C. O.: Global distribution and seasonality of active fires as observed with the Terra and Aqua Moderate Resolution Imaging Spectroradiometer (MODIS) sensors, J. Geophys. Res.-Biogeo., 111, G02016, https://doi.org/10.1029/2005JG000142, 2006.

Gilman, J. B., Lerner, B. M., Kuster, W. C., and de Gouw, J. A.: Source signature of volatile organic compounds from oil and natural gas operations in northeastern Colorado, Environ. Sci. Technol., 47, 1297-1305, https://doi.org/10.1021/es304119a, 2013.

Gilman, J. B., Lerner, B. M., Kuster, W. C., Goldan, P. D., Warneke, C., Veres, P. R., Roberts, J. M., de Gouw, J. A., Burling, I. 
R., and Yokelson, R. J.: Biomass burning emissions and potential air quality impacts of volatile organic compounds and other trace gases from fuels common in the US, Atmos. Chem. Phys., 15, 13915-13938, https://doi.org/10.5194/acp-15-139152015, 2015.

Giordano, M. R., Chong, J., Weise, D. R., and Asa-Awuku, A. A.: Does chronic nitrogen deposition during biomass growth affect atmospheric emissions from biomass burning?, Environ. Res. Lett., 11, 034007 https://doi.org/10.1088/17489326/11/3/034007, 2016.

Goode, J. G., Yokelson, R. J., Ward, D. E., Susott, R. A., Babbitt, R. E., Davies, M. A., and Hao, W. M.: Measurements of excess $\mathrm{O} 3, \mathrm{CO} 2, \mathrm{CO}, \mathrm{CH} 4, \mathrm{C} 2 \mathrm{H} 4, \mathrm{C} 2 \mathrm{H} 2, \mathrm{HCN}, \mathrm{NO}, \mathrm{NH} 3$, $\mathrm{HCOOH}, \mathrm{CH} 3 \mathrm{COOH}, \mathrm{HCHO}$, and $\mathrm{CH} 3 \mathrm{OH}$ in 1997 Alaskan biomass burning plumes by airborne Fourier transform infrared spectroscopy (AFTIR), J. Geophys. Res.-Atmos., 105, 2214722166, doi10.1029/2000JD900287, 2000.

Guenther, A., Karl, T., Harley, P., Wiedinmyer, C., Palmer, P. I., and Geron, C.: Estimates of global terrestrial isoprene emissions using MEGAN (Model of Emissions of Gases and Aerosols from Nature), Atmos. Chem. Phys., 6, 3181-3210, https://doi.org/10.5194/acp-6-3181-2006, 2006.

Heilman, W. E., Liu, Y., Urbanski, S., Kovalev, V., and Mickler, R.: Wildland fire emissions, carbon, and climate: Plume rise, atmospheric transport, and chemistry processes, Forest Ecol. Manage., 317, 70-79, https://doi.org/10.1016/j.foreco.2013.02.001, 2014.

Hobbs, P. V., Sinha, P., Yokelson, R. J., Christian, T. J., Blake, D. R., Gao, S., Kirchstetter, T. W., Novakov, T., and Pilewskie, P.: Evolution of gases and particles from a savanna fire in South Africa, J. Geophys. Res.-Atmos., 108, 8485, https://doi.org/10.1029/2002JD002352, 2003.

Jacob, D. J., Logan, J. A., Yevich, R. M., Gardner, G. M., Spivakovsky, C. M., Wofsy, S. C., Munger, J. W., Sillman, S., Prather, M. J., Rodgers, M. O., Westberg, H., and Zimmerman, P. R.: Simulation of summertime ozone over North America, J. Geophys. Res.-Atmos., 98, 14797-14816, https://doi.org/10.1029/93JD01223, 1993.

Jaegle, L., Steinberger, L., Martin, R. V., and Chance, K.: Global partitioning of NOx sources using satellite observations: Relative roles of fossil fuel combustion, biomass burning and soil emissions, Faraday Discuss., 130, 407-423, https://doi.org/10.1039/B502128F, 2005.

Jaffe, D. A., Chand, D., Hafner, W., Westerling, A., and Spracklen, D.: Influence of fires on O-3 concentrations in the western US, Environ. Sci. Technol., 42, 5885-5891, https://doi.org/10.1021/es800084k, 2008.

Jaffe, D. A. and Wigder, N. L.: Ozone production from wildfires: A critical review, Atmos. Environ., 51, 1-10, https://doi.org/10.1016/j.atmosenv.2011.11.063, 2012.

Kalnay, E., Kanamitsu, M., Kistler, R., Collins, W., Deaven, D., Gandin, L., Iredell, M., Saha, S., White, G., Woollen, J., Zhu, Y., Leetmaa, A., Reynolds, R., Chelliah, M., Ebisuzaki, W., Higgins, W., Janowiak, J., Mo, K. C., Ropelewski, C., Wang, J., Jenne, R., and Joseph, D.: The NCEP/NCAR 40-Year Reanalysis Project, Bu. Am. Meteor. Soc., 77, 437-471, https://doi.org/10.1175/15200477(1996)077<0437:TNYRP>2.0.CO;2, 1996.
Kelly, T. J., Stedman, D. H., and Kok, G. L.: Measurements of H2O2 and HNO3in rural air, Geophys. Res. Lett., 6, 375-378, https://doi.org/10.1029/GL006i005p00375, 1979.

Kley, D. and McFarland, M.: Chemiluminescence detector for NO and NO2, J. Atmos. Technol., 12, 62-69, 1980.

Künzli, N., Avol, E., Wu, J., Gauderman, W. J., Rappaport, E., Millstein, J., Bennion, J., McConnell, R., Gilliland, F. D., Berhane, K., Lurmann, F., Winer, A., and Peters, J. M.: Health Effects of the 2003 Southern California Wildfires on Children, American Journal of Respiratory and Critical Care Medicine, 174, 12211228, https://doi.org/10.1164/rccm.200604-519OC, 2006.

Lacaux, J. P., Delmas, R., Jambert, C., and Kuhlbusch, T. A. J.: NOx emissions from African savanna fires, J. Geophys. Res.-Atmos. 101, 23585-23595, https://doi.org/10.1029/96JD01624, 1996.

Liu, X., Zhang, Y., Huey, L. G., Yokelson, R. J., Wang, Y., Jimenez, J. L., Campuzano-Jost, P., Beyersdorf, A. J., Blake, D. R., Choi, Y., St. Clair, J. M., Crounse, J. D., Day, D. A., Diskin, G. S., Fried, A., Hall, S. R., Hanisco, T. F., King, L. E., Meinardi, S., Mikoviny, T., Palm, B. B., Peischl, J., Perring, A. E., Pollack, I. B., Ryerson, T. B., Sachse, G., Schwarz, J. P., Simpson, I. J., Tanner, D. J., Thornhill, K. L., Ullmann, K., Weber, R. J., Wennberg, P. O., Wisthaler, A., Wolfe, G. M., and Ziemba, L. D.: Agricultural fires in the southeastern US during SEAC4RS: Emissions of trace gases and particles and evolution of ozone, reactive nitrogen, and organic aerosol, J. Geophys. Res.-Atmos., 121, 73837414, https://doi.org/10.1002/2016JD025040, 2016.

Lu, X., Zhang, L., Yue, X., Zhang, J., Jaffe, D. A., Stohl, A., Zhao, Y., and Shao, J.: Wildfire influences on the variability and trend of summer surface ozone in the mountainous western United States, Atmos. Chem. Phys., 16, 14687-14702, https://doi.org/10.5194/acp-16-14687-2016, 2016.

Mason, S. A., Field, R. J., Yokelson, R. J., Kochivar, M. A., Tinsley, M. R., Ward, D. E., and Hao, W. M.: Complex effects arising in smoke plume simulations due to inclusion of direct emissions of oxygenated organic species from biomass combustion, J. Geophys. Res.-Atmos., 106, 1252712539, https://doi.org/10.1029/2001JD900003, 2001.

McClure-Begley, A., Petropavlovskikh, I., and Oltmans, S.: NOAA Global Monitoring Surface Ozone Network, BAO, June 2015September 2015, National Oceanic and Atmospheric Administration, Earth Systems Research Laboratory Global Monitoring Division, Boulder, CO, https://doi.org/10.7289/V57P8WBF, 2014.

McDuffie, E. E., Edwards, P. M., Gilman, J. B., Lerner, B. M., Dubé, W. P., Trainer, M., Wolfe, D. E., Angevine, W. M., deGouw, J., Williams, E. J., Tevlin, A. G., Murphy, J. G., Fischer, E. V., McKeen, S., Ryerson, T. B., Peischl, J., Holloway, J. S., Aikin, K., Langford, A. O., Senff, C. J., Alvarez, R. J., Hall, S. R., Ullmann, K., Lantz, K. O., and Brown, S. S.: Influence of oil and gas emissions on summertime ozone in the Colorado Northern Front Range, J. Geophys. Res.-Atmos., 121, 8712-8729, https://doi.org/10.1002/2016JD025265, 2016.

McManus, J. B., Zahniser, M. S., and Nelson, D. D.: Dual quantum cascade laser trace gas instrument with astigmatic Herriott cell at high pass number, Appl. Opt., 50, A74-A85, https://doi.org/10.1364/AO.50.000A74, 2011

McMeeking, G. R., Kreidenweis, S. M., Baker, S., Carrico, C. M., Chow, J. C., Collett, J. L., Hao, W. M., Holden, A. S., Kirchstetter, T. W., Malm, W. C., Moosmüller, H., Sullivan, A. P., and 
Wold, C. E.: Emissions of trace gases and aerosols during the open combustion of biomass in the laboratory, J. Geophys. Res.Atmos., 114, D19210, https://doi.org/10.1029/2009JD011836, 2009.

Moody, J. L., Munger, J. W., Goldstein, A. H., Jacob, D. J., and Wofsy, S. C.: Harvard Forest regional-scale air mass composition by Patterns in Atmospheric Transport History (PATH), J. Geophys. Res.-Atmos., 103, 13181-13194, https://doi.org/10.1029/98JD00526, 1998.

Morris, G. A., Hersey, S., Thompson, A. M., Pawson, S., Nielsen, J. E., Colarco, P. R., McMillan, W. W., Stohl, A., Turquety, S., Warner, J., Johnson, B. J., Kucsera, T. L., Larko, D. E., Oltmans, S. J., and Witte, J. C.: Alaskan and Canadian forest fires exacerbate ozone pollution over Houston, Texas, on 19 and 20 July 2004, J. Geophys. Res.-Atmos., 111, D04304, https://doi.org/10.1029/2006JD007090, 2006.

Pétron, G., Frost, G., Miller, B. R., Hirsch, A. I., Montzka, S. A., Karion, A., Trainer, M., Sweeney, C., Andrews, A. E., Miller, L., Kofler, J., Bar-Ilan, A., Dlugokencky, E. J., Patrick, L., Moore, C. T., Ryerson, T. B., Siso, C., Kolodzey, W., Lang, P. M., Conway, T., Novelli, P., Masarie, K., Hall, B., Guenther, D., Kitzis, D., Miller, J., Welsh, D., Wolfe, D., Neff, W., and Tans, P.: Hydrocarbon emissions characterization in the Colorado Front Range: A pilot study, J. Geophys. Res.-Atmos., 117, L19814, https://doi.org/10.1029/2011JD016360, 2012.

Pétron, G., Karion, A., Sweeney, C., Miller, B. R., Montzka, S. A., Frost, G. J., Trainer, M., Tans, P., Andrews, A., Kofler, J., Helmig, D., Guenther, D., Dlugokencky, E., Lang, P., Newberger, T., Wolter, S., Hall, B., Novelli, P., Brewer, A., Conley, S., Hardesty, M., Banta, R., White, A., Noone, D., Wolfe, D., and Schnell, R.: A new look at methane and nonmethane hydrocarbon emissions from oil and natural gas operations in the Colorado Denver-Julesburg Basin, J. Geophys. Res.-Atmos., 119, 6836-6852, https://doi.org/10.1002/2013JD021272, 2014.

Pfister, G. G., Wiedinmyer, C., and Emmons, L. K.: Impacts of the fall 2007 California wildfires on surface ozone: Integrating local observations with global model simulations, Geophys. Res. Lett., 35, L12808, https://doi.org/10.1029/2008GL034747, 2008.

Pinder, R. W., Gilliland, A. B., and Dennis, R. L.: Environmental impact of atmospheric NH3 emissions under present and future conditions in the eastern United States, Geophys. Res. Lett., 35, L12808, https://doi.org/10.1029/2008GL033732, 2008.

Rappold, A. G., Stone, S. L., Cascio, W. E., Neas, L. M., Kilaru, V. J., Carraway, M. S., Szykman, J. J., Ising, A., Cleve, W. E., Meredith, J. T., Vaughan-Batten, H., Deyneka, L., and Devlin, R. B.: Peat Bog Wildfire Smoke Exposure in Rural North Carolina Is Associated with Cardiopulmonary Emergency Department Visits Assessed through Syndromic Surveillance, Environ. Health Persp., 119, 1415-1420, https://doi.org/10.1289/ehp.1003206, 2011.

Reddy, P. J. and Pfister, G. G.: Meteorological factors contributing to the interannual variability of midsummer surface ozone in Colorado, Utah, and other western US states, J. Geophys. Res.-Atmos., 121, 2434-2456, https://doi.org/10.1002/2015JD023840, 2016.

Rhew, R. C., Deventer, M. J., Turnipseed, A. A., Warneke, C., Ortega, J., Shen, S., Martinez, L., Koss, A., Lerner, B. M., Gilman, J. B., Smith, J. N., Guenther, A. B., and de Gouw, J. A.: Ethene, propene, butene and isoprene emissions from a ponderosa pine forest measured by Relaxed Eddy Accumulation, Atmos. Chem. Phys. Discuss., https://doi.org/10.5194/acp-2017-363, in review, 2017.

Rolph, G. D., Draxler, R. R., Stein, A. F., Taylor, A., Ruminski, M. G., Kondragunta, S., Zeng, J., Huang, H.-C., Manikin, G., McQueen, J. T., and Davidson, P. M.: Description and Verification of the NOAA Smoke Forecasting System: The 2007 Fire Season, Weather Forecast., 24, 361-378, https://doi.org/10.1175/2008WAF2222165.1, 2009.

Roscioli, J. R., Zahniser, M. S., Nelson, D. D., Herndon, S. C., and Kolb, C. E.: New Approaches to Measuring Sticky Molecules: Improvement of Instrumental Response Times Using Active Passivation, J. Phys. Chem. A, 120, 1347-1357, doi10.1021/acs.jpca.5b04395, 2016.

Rudolph, J. and Ehhalt, D. H.: Measurements of C2-C5 hydrocarbons over the North Atlantic, J. Geophys. Res.-Oceans, 86, 11959-11964, https://doi.org/10.1029/JC086iC12p11959, 1981.

Schreier, S. F., Richter, A., Schepaschenko, D., Shvidenko, A., Hilboll, A., and Burrows, J. P.: Differences in satellitederived NOx emission factors between Eurasian and North American boreal forest fires, Atmos. Environ., 121, 55-65, https://doi.org/10.1016/j.atmosenv.2014.08.071, 2015.

Sillman, S.: The relation between ozone, NOx, and hydrocarbons in urban and polluted rural environments, Atmos. Environ., 33, 1821-1845, 1999.

Singh, H. B. and Hanst, P. L.: Peroxyacetyl nitrate (PAN) in the unpolluted atmosphere: An important reservoir for nitrogen oxides, Geophys. Res. Lett., 8, 941-944, https://doi.org/10.1029/GL008i008p00941, 1981.

Singh, H. B., Cai, C., Kaduwela, A., Weinheimer, A., and Wisthaler, A.: Interactions of fire emissions and urban pollution over California: Ozone formation and air quality simulations, Atmos. Environ., 56, 45-51, https://doi.org/10.1016/j.atmosenv.2012.03.046, 2012.

Sive, B. C., Zhou, Y., Troop, D., Wang, Y., Little, W. C., Wingenter, O. W., Russo, R. S., Varner, R. K., and Talbot, R.: Development of a Cryogen-Free Concentration System for Measurements of Volatile Organic Compounds, Anal. Chem., 77, 69896998, https://doi.org/10.1021/ac0506231, 2005.

Stein, A. F., Draxler, R. R., Rolph, G. D., Stunder, B. J. B., Cohen, M. D., and Ngan, F.: NOAA's HYSPLIT Atmospheric Transport and Dispersion Modeling System, Bu. Am. Meteor. Soc., 96, 2059-2077, https://doi.org/10.1175/BAMS-D-14$00110.1,2015$.

Stockwell, C. E., Veres, P. R., Williams, J., and Yokelson, R. J.: Characterization of biomass burning emissions from cooking fires, peat, crop residue, and other fuels with high-resolution proton-transfer-reaction time-of-flight mass spectrometry, Atmos. Chem. Phys., 15, 845-865, https://doi.org/10.5194/acp-15845-2015, 2015.

Sullivan, J. T., McGee, T. J., Langford, A. O., Alvarez, R. J., Senff, C. J., Reddy, P. J., Thompson, A. M., Twigg, L. W., Sumnicht, G. K., Lee, P., Weinheimer, A., Knote, C., Long, R. W., and Hoff, R. M.: Quantifying the contribution of thermally driven recirculation to a high-ozone event along the Colorado Front Range using lidar, J. Geophys. Res.-Atmos., 121, 1,377-310390, https://doi.org/10.1002/2016JD025229, 2016.

Swarthout, R. F., Russo, R. S., Zhou, Y., Hart, A. H., and Sive, B. C.: Volatile organic compound distributions during the NACHTT 
campaign at the Boulder Atmospheric Observatory: Influence of urban and natural gas sources, J. Geophys. Res.-Atmos., 118, 10614-610637, https://doi.org/10.1002/jgrd.50722, 2013.

Tabazadeh, A., Jacobson, M. Z., Singh, H. B., Toon, O. B., Lin, J. S., Chatfield, R. B., Thakur, A. N., Talbot, R. W., and Dibb, J. E.: Nitric acid scavenging by mineral and biomass burning aerosols, Geophys. Res. Lett., 25, 4185-4188, https://doi.org/10.1029/1998GL900062, 1998.

Thompson, C. R., Hueber, J., and Helmig, D.: Influence of oil and gas emissions on ambient atmospheric nonmethane hydrocarbons in residential areas of Northeastern Colorado, Elementa: Science of the Anthropocene, 2, 3-35, https://doi.org/10.12952/journal.elementa.000035, 2014.

Townsend-Small, A., Botner, E. C., Jimenez, K. L., Schroeder, J. R., Blake, N. J., Meinardi, S., Blake, D. R., Sive, B. C., Bon, D., Crawford, J. H., Pfister, G., and Flocke, F. M.: Using stable isotopes of hydrogen to quantify biogenic and thermogenic atmospheric methane sources: A case study from the Colorado Front Range, Geophys. Res. Lett., 43, 11462-411471, https://doi.org/10.1002/2016GL071438, 2016.

Trainer, M., Parrish, D. D., Buhr, M. P., Norton, R. B., Fehsenfeld, F. C., Anlauf, K. G., Bottenheim, J. W., Tang, Y. Z., Wiebe, H. A., Roberts, J. M., Tanner, R. L., Newman, L., Bowersox, V. C., Meagher, J. F., Olszyna, K. J., Rodgers, M. O., Wang, T., Berresheim, H., Demerjian, K. L., and Roychowdhury, U. K.: Correlation of ozone with $\mathrm{NO}_{y}$ in photochemically aged air, J. Geophys. Res.-Atmos., 98, 2917-2925, https://doi.org/10.1029/92JD01910, 1993.

Trentmann, J., Yokelson, R. J., Hobbs, P. V., Winterrath, T., Christian, T. J., Andreae, M. O., and Mason, S. A.: An analysis of the chemical processes in the smoke plume from a savanna fire, J. Geophys. Res.-Atmos., 110, D12301, https://doi.org/10.1029/2004JD005628, 2005.

Val Martin, M., Heald, C. L., Lamarque, J. F., Tilmes, S., Emmons, L. K., and Schichtel, B. A.: How emissions, climate, and land use change will impact mid-century air quality over the United States: a focus on effects at national parks, Atmos. Chem. Phys., 15, 2805-2823, https://doi.org/10.5194/acp15-2805-2015, 2015.
Vu, K. T., Dingle, J. H., Bahreini, R., Reddy, P. J., Apel, E. C., Campos, T. L., DiGangi, J. P., Diskin, G. S., Fried, A., Herndon, S. C., Hills, A. J., Hornbrook, R. S., Huey, G., Kaser, L., Montzka, D. D., Nowak, J. B., Pusede, S. E., Richter, D., Roscioli, J. R., Sachse, G. W., Shertz, S., Stell, M., Tanner, D., Tyndall, G. S., Walega, J., Weibring, P., Weinheimer, A. J., Pfister, G., and Flocke, F.: Impacts of the Denver Cyclone on regional air quality and aerosol formation in the Colorado Front Range during FRAPPÉ 2014, Atmos. Chem. Phys., 16, 12039-12058, https://doi.org/10.5194/acp-16-12039-2016, 2016.

Westerling, A. L.: Increasing western US forest wildfire activity: sensitivity to changes in the timing of spring, Philos. T. R. Soc. B, 371, 20150178, https://doi.org/10.1098/rstb.2015.0178, 2016.

Yates, E. L., Iraci, L. T., Singh, H. B., Tanaka, T., Roby, M. C., Hamill, P., Clements, C. B., Lareau, N., Contezac, J., Blake, D. R., Simpson, I. J., Wisthaler, A., Mikoviny, T., Diskin, G. S., Beyersdorf, A. J., Choi, Y., Ryerson, T. B., Jimenez, J. L., Campuzano-Jost, P., Loewenstein, M., and Gore, W.: Airborne measurements and emission estimates of greenhouse gases and other trace constituents from the 2013 California Yosemite Rim wildfire, Atmos. Environ., 127, 293-302, https://doi.org/10.1016/j.atmosenv.2015.12.038, 2016.

Yokelson, R. J., Crounse, J. D., DeCarlo, P. F., Karl, T., Urbanski, S., Atlas, E., Campos, T., Shinozuka, Y., Kapustin, V., Clarke, A. D., Weinheimer, A., Knapp, D. J., Montzka, D. D., Holloway, J., Weibring, P., Flocke, F., Zheng, W., Toohey, D., Wennberg, P. O., Wiedinmyer, C., Mauldin, L., Fried, A., Richter, D., Walega, J., Jimenez, J. L., Adachi, K., Buseck, P. R., Hall, S. R., and Shetter, R.: Emissions from biomass burning in the Yucatan, Atmos. Chem. Phys., 9, 5785-5812, https://doi.org/10.5194/acp-9-57852009, 2009.

Zaragoza, J.: Observations of acyl peroxy nitrates during the Front Range Air Pollution And Photochemistry Éxperiment (FRAPPÉ), Master of Science (M.S.), Atmospheric Science, Colorado State University, 78 pp., 2016. 